\title{
Should California's Film Script Cases Be Merged into Trade Secret Law?
}

\author{
Charles Tait Graves*
}

\begin{abstract}
In legal disputes where one party claims that it submitted an idea to another party and alleges that the latter used that idea without permission or compensation, two categories of California intellectual property law have increasingly come to resemble one another: (1) trade secret law, most often applied in business or technical contexts; and (2) idea submission law, primarily applied in cases involving film scripts and other media productions. Over the decades, these regimes have developed separately, within distinct business and legal cultures. But recent developments in California trade secret law have brought the two closer together; in some areas, they may even be approaching a unified body of law. This Article explores that possibility. It concludes that although a partial merger is inevitable, the two core causes of action - for asserted trade secrets, a misappropriation claim; for idea submissions, a so-called Desny claim for breach of implied-in-fact contractwill and should remain distinct. A partial merger, however, would lead to beneficial exchanges in areas where their doctrines already overlap: (1) idea submission's "independent development" and trade secret's "independent derivation" defenses; and (2) statutory preemption under California's Uniform Trade Secrets Act (CUTSA).

California's idea submission cases have developed sophisticated and robust means to adjudicate the concept of "independent development"- that is, a defendant's assertion that despite receiving the plaintiff's idea, it nonetheless came up with the disputed film, television show, or other concept on its own. By contrast, the important and analogous defense of "independent derivation" in California trade secret law remains underdeveloped. This Article argues that the idea submission cases offer a far more rigorous analysis of the defense and could inform similar decisions under trade secret law. In particular, it proposes a methodology that courts can use to adjudicate the independent derivation defense, inspired by the idea submission cases.
\end{abstract}

* Partner, Wilson Sonsini, San Francisco; adjunct faculty, UC Hastings Law. I thank Robert Denicola, Camilla Hrdy, Riana Pfefferkorn, James Pooley, Sharon Sandeen, and Deepa Varadarajan for their helpful input and suggestions.

(C) 2020 Graves. This is an open access article distributed under the terms of the Creative Commons Attribution License, which permits unrestricted use, distribution, and reproduction, provided the original author and source are credited. 
The idea submission cases largely survived copyright preemption challenges in the 1990s and 2000s after Ninth Circuit rulings preserved the viability of some idea submission causes of action under state law. But surviving copyright preemption is not the same thing as surviving CUTSA trade secret preemption. This more recent form of IP preemption is broad, and it subsumes tort claims seeking to protect information said to be confidential. This Article argues that the CUTSA preempts peripheral idea submission tort claims such as breach of confidence, but it does not preempt the core claim at the heart of California's idea submission regime- the Desny claim for breach of implied-in-fact contract.

The proposed partial merger recognizes the public policy ends of each regime: protecting weaker parties who submit ideas to film and media studios (in narrowlydefined circumstances), and ensuring that litigants cannot use tort claims to subvert the protections the CUTSA and related employee mobility rules provide for the free use of publicly available information that does not meet the statutory definition of a trade secret.

Abstract . 21

Introduction

I. Overlapping Narratives and Fuzzy Boundaries: Idea Submission versus

Trade Secrecy...

II. A History of Idea Submission as a Category of California Intellectual

Property Law....

III. Should California's Trade Secret and Idea Submission Regimes Be Merged?

A. Borrowing from Independent Development To Bring

Independent Derivation Out of the Shadows....

1. Independent Derivation in California Trade Secret Law .....42

2. Independent Development in California Idea Submission Law.....

3. Bringing the Idea Submission Independent Development Methodology into Trade Secret Law ....

B. Preemption of Common Law Intellectual Property Tort Claims: Does the California Uniform Trade Secret Act Preempt Any Idea Submission Theories? ....

1. California Idea Submission Claims and Partial Copyright Preemption

2. Trade Secret Preemption of California Idea Submission Claims

a. A History of Uniform Trade Secrets Act Preemption in California

b. The California Uniform Trade Secrets Act Preempts Idea Submission Torts Premised on Confidential Information 


\section{c. California's Uniform Trade Secrets Act Preemption Does Not Apply To Desny Claims.}

\section{INTRODUCTION}

If someone discloses an idea to a company in the hopes of effectuating a transaction, and the company uses that idea for its own benefit without permission or compensation, does that person have a claim under California law? And assuming they do, which legal regime will be most effective: trade secret law or idea submission law? If the former, the claim would arise under California's Uniform Trade Secret Act (CUTSA), which has become one of the major regimes through which technology disputes in Silicon Valley and elsewhere are adjudicated. If the latter - a creature of Southern California's film and media industries - the claim would likely proceed as an implied-in-fact contract claim.

These answers are not as clear as they used to be. The two legal regimes cover similar ground, with some cases sharing nearly identical fact patterns. As the scope of California's trade secret law has expanded in recent years, the boundaries between trade secret and idea submission laws have blurred. This Article - the first to bring together these areas of California intellectual property law for sustained analysisexamines how those boundaries have shifted. It asks whether California's trade secret and idea submission laws should be merged and, regardless, whether courts can benefit from consolidating case law where there is clear overlap. ${ }^{1}$

On the one hand, California has developed a robust body of law regarding idea submissions within the entertainment context. By the 1950s, courts recognized a theory of implied-in-fact contract that protects a weaker party who submits a film script or other idea to a more powerful studio - even when the idea itself was not entirely novel. Such "Desny claims" are named for a landmark 1956 California Supreme Court decision, which crafted the elements of the implied-in-fact-contract claim still used today. ${ }^{2}$ At the same time, plaintiffs in idea submission cases often assert a host of additional tort claims, such as breach of confidence, based on the premise that the plaintiff's idea was confidential. In response to Desny claims, defendants have raised a defense of "independent development," asserting that even if the defendant did receive the submission from the plaintiff, the origin of the defendant's similar film or television concept came from a different source, in which case they would not be liable.

Idea submission claims were entangled in copyright preemption disputes during the 1990s and 2000s, as scholars and courts wrestled with the question whether ideas in the entertainment context fell within the scope of the Copyright Act's preemption

1. One need not advocate the complete merger of two overlapping areas of law to recognize the benefits of merging certain parts. See, e.g., Rebecca Tushnet, Running the Gamut from A To B: Federal Trademark and False Advertising Law, 159 U. PA. L. REV. 1305, 1360 (2011) (proposing that trademark law borrow from the concept of materiality in false advertising law to "require courts to consider why (or when) confusion is harmful").

2. See Desny v. Wilder, 46 Cal. 2d 715 (1956). 
clause. $^{3}$ The Ninth Circuit has largely found that federal copyright law does not preempt such claims. As a result, this state-created category of intellectual property protection for business ideas has survived.

On the other hand, California's trade secret laws have expanded in subject matter and in the degree to which the CUSTA is found to preempt other tort claims that allege misuse of confidential business information, such as breach of confidence, conversion, and unfair competition. In 2014, a California court specifically ruled that state trade secret law does protect ideas, even if such ideas are not-in patent parlance-reduced to practice. ${ }^{4}$ And, especially since the first state appellate decision in 2009, courts have broadly construed the preemptive reach of California's trade secret statute to preclude soundalike tort claims such as breach of confidence. ${ }^{5}$

As a result of this expansion of trade secret law, a California plaintiff bringing an idea submission claim conceivably could allege a trade secret claim in place of an idea submission claim in at least some contexts. Indeed, parties have brought claims under one approach or the other in cases with similar fact patterns. Despite decades of case law in both areas, however, the courts have not squarely considered whether California's trade secret law overlaps with, or subsumes in whole or in part, its idea submission cases. That silence may reflect accidents of culture and geography: Trade secret and entertainment law specialists rarely mix, whether in practice or in academia, and they tend to see one another as covering entirely different practice areas. Although the divide between Hollywood and Silicon Valley-media and tech - is narrowing, it was and remains real. Indeed, from the perspective of trade secret law, California's idea submission law can seem distinctly anachronistic, with its reliance on musty tort labels and theories developed decades ago, back when trade secret law was in its relative youth.

In that sense, this Article is about how concepts circulate (or don't) among the legal profession, as much as it is a formal study of whether two similar legal regimes should be merged. Between Northern and Southern California, tech and Hollywood, and IP and entertainment law, with their different nomenclatures and other clichéd differences, all sides have much to learn. Indeed, in a state that alone would comprise one of the world's largest economies, ${ }^{6}$ and with the tech and entertainment worlds trending ever closer, we may ask whether the time for regionally-centered, inconsistent intellectual property regimes has passed.

This study concludes that a partial merger of these areas of law is desirable as public policy, and required by statute. It also concludes that a total merger is not possible. To begin with, the Desny contract claim is not preempted by the CUTSAunlike other idea submission claims that sound in tort. Also, the Desny claim does not entirely require a showing of what California courts have labeled "novelty"-

3. 17 U.S.C. $\S 301$

4. See Altavion, Inc. v. Konica Minolta Sys. Lab’y Inc., 226 Cal. App. 4th 26 (2014).

5. See K.C. Multimedia, Inc. v. Bank of Am. Tech. \& Operations, Inc., 171 Cal. App. 4th 939, 957-60 (2009); Silvaco Data Sys. v. Intel Corp., 184 Cal. App. 4th 210, 232-40 (2010), overruled in part on unrelated grounds by Kwikset v. Superior Court, 51 Cal. 4th 310, 336-39, 336 n.22 (2011).

6. See California Economy Passes UK's To Become World's Fifth Biggest, GuARDian (May 4, 2018), https://perma.cc/99V4-L5MN. 
meaning, the idea can be publicly available to some degree - and therefore it is not equivalent to a trade secret claim. Nonetheless, there are two areas in particular where subject-matter overlap should result in salutary outcomes. California courts can act on both without altering current law.

First, California's robust case law defining the independent development defense within the idea submission context provides a highly useful analog that could help courts to better organize the important, but poorly developed, defense of independent derivation in the trade secret context. Part of what distinguishes trade secret law from patent protection is that a trade secret does not grant monopoly rights; anyone else is free to conceive and practice the same secret idea, invention, or development so long as they did not misappropriate it. Independent derivation is therefore a foundational feature of trade secret law. It ensures the rights of others to independently create similar information without liability to the first-in-time creator. Nevertheless, courts have yet to develop a well-structured framework for analyzing the independent derivation defense. Published decisions, in California and elsewhere, remain scarce.

Borrowing from decades of case law on independent development in the idea submission context, this Article is the first to propose a structural framework for organizing the independent derivation defense. This framework includes two key elements. First, it focuses on the temporal aspect - whether the defendant claims to have conceived the independent idea before or after receiving the plaintiff's ideas. Second, it considers the identity of the person or entity claiming to have independently derived the plaintiff's trade secret—whether it is the same individual who received the trade secret, his or her new co-worker at the same company, or a third party working with the new employer. By focusing on the timing of the claimed independent derivation and the identity of the claimed independent source, courts can better weigh whether the defendant has established its burden of producing viable evidence to support the defense.

The idea submission cases have developed extensive decisional law defining how to establish (or defeat) the independent development defense. While none of these cases formally recognize the time-and-source methodology this Article proposes, a close analysis of the case law shows that courts are applying this methodology in practice. Courts should apply this methodology to the trade secret context as well, because the central questions are directly analogous.

The second area of beneficial overlap involves California Uniform Trade Secrets Act preemption - a doctrine that blocks any California tort claims pertaining to misuse of confidential business information. Such preemption should also be applied to trade secret-like tort claims when asserted in the idea submission context. This would eliminate causes of action, like breach of confidence, that are premised on the asserted confidentiality of an idea. Importantly, CUTSA preemption would not supplant the core Desny claim for breach of implied-in-fact contract, because the trade secret statute does not preempt "contractual remedies."

In both the trade secret and the idea submission contexts, plaintiffs often attempt to bring nebulous tort claims - such as breach of confidence, conversion, and unfair competition - in an effort to increase their chances by circumventing the limitations 
imposed by the two core causes of action: statutory trade secret and breach of contract claims. Because the sweep of CUTSA preemption is broad, it should also apply in the idea submission context, where the tort claims raised are purportedly based on nonpublic business ideas, as when breach of confidence is alleged. The preemption doctrine serves important policy objectives. It prevents litigants from pleading around the rules and requirements of the trade secret statute in an attempt to protect information that would not qualify for statutory protection. It therefore protects the right to use publicly available information without fear of liability under some unpredictable, made-for-litigation tort theory.

In this manner, applying CUTSA preemption to the idea submission context would result in a partial, but not a complete, merger of California's trade secret and idea submission regimes. This would still leave litigants with several options: a cause of action for misappropriation of trade secrets, a claim for breach of a written contract (if one exists), or the Desny claim (in a narrow context defined by that landmark case). It would also preserve a notable point of similarity between the two regimes. In both cases, but in almost opposite ways, California's trade secret and idea submission laws generally operate to protect the weaker party.

Specifically, in idea submission disputes, the Desny implied contract claim does not require the person who submitted an idea to a studio to prove that the idea was novel (and thus not known to others). Separately, and almost unique among the states, California's employee mobility and trade secret laws have developed together to ban non-competition and non-solicitation covenants and to prohibit other types of overreaching attacks by former employers against departing employees. California law therefore prioritizes the weaker party in employee mobility disputes by ensuring that non-secret, publicly available information is freely transportable from job to job. In contrast with a Desny claim, a trade secret claimant must demonstrate that the disputed information is protectable under an objective standard, not merely in a subjective sense. Even where idea submission cases and trade secret law are brought closer together, this critical distinction will remain.

This Article proceeds in four parts. Part I demonstrates that the boundaries between California trade secret and idea submission law have not always been clear. Part II provides a history of how California's idea submission cases reached their present form, with a review of virtually all reported case law over the decades. ${ }^{7}$ Part III discusses points of convergence and variance between these two areas of law, and offers guidance for integrating their insights. Part III.A proposes that courts analyzing the defense of independent derivation in trade secret cases use a time- and source-based methodology, borrowed from the idea submission cases, to better weigh the defendant's evidence in such cases. Part III.B explains how California courts have broadly construed the preemptive scope of the CUTSA in recent years,

7. This Article summarizes research on California idea submission cases, believed to be reasonably complete through June 2020. As is always the case when conducting research into trial court rulings, case records are necessarily incomplete. California trial court rulings are largely unavailable on databases such as Westlaw, Lexis, and Google Scholar, and older federal district court rulings may be unavailable as well. In addition, term searches in these databases may miss some cases. No treatise or other source compiles a complete set of them. 
and why that means tort claims - but not contract claims - asserted in the idea submission context are preempted by the statute. ${ }^{8}$

\section{OVERLAPPING NARRATIVES AND FUZZY BOUNDARIES: IDEA SUBMISSION VERSUS TRADE SECRECY}

To set the stage for a discussion about merging California's trade secret and idea submission regimes, we begin with the ambiguous boundary between them. In general, a trade secret claim covers any nonpublic business information that is valuable to competitors due to secrecy and is reasonably guarded by the claimant. ${ }^{9}$ The classic trade secret dispute involves a former employer and a former employee, but trade secret claims are not limited to that context. An idea submission tort claim such as breach of confidence covers information said to be "confidential and novel." 10 And, as described below, a Desny claim for breach of implied contract does not require a novel idea, but it does require that the idea is not merely a recitation of known facts, and that the plaintiff has not previously published the idea, did not reveal it in a more general business pitch, and submitted it only in a narrow offerfor-sale scenario. ${ }^{11}$ In the classic idea submission case, someone has pitched an entertainment idea to a studio or producer; but again, idea submission claims do not always fall neatly into that scenario.

Under each type of claim, the plaintiff alleges that they provided valuable business information that the defendant then misused, without permission and without compensation. The ambiguity among these claims is strongest not when a dispute is centered on employee mobility - that is, a case where an employee has left one company and joined or started another-but where one business alleges that it disclosed an idea, plan, or concept to another business, and alleges that the defendant proceeded to use that information without compensation or permission. ${ }^{12}$ In such

8. This conclusion also answers questions raised in an earlier publication. Years ago, this author wrote a history of California's pre-1985, pre-CUTSA trade secret case law, found that California trade secret law never recognized a category of "confidential but not secret" information, and thus predictedcorrectly - that California courts would adopt a strong view of CUTSA trade secret preemption of various tort claims. But the history of the idea submission cases was too far afield to cover in that study. The article merely noted, in passing, that idea submission tort claims like breach of confidence are probably CUTSA-preempted. See Tait Graves, Nonpublic Information and California Tort Law: A Proposal for Harmonizing California's Employee Mobility and Intellectual Property Regimes Under the Uniform Trade Secrets Act, 2006 UCLA J.L. \& TECH. 1 (2006). Some fifteen years later, and in view of the direction California courts have taken since, that conclusion is stronger than ever.

9. See CAL. Civ. Code $§ 3426.1$ (d) (West 2020). A federal claim under the Defend Trade Secrets Act requires the plaintiff to establish a fourth element- that the information is not readily ascertainable. See 18 U.S.C. $\S 1839(3)(b)$. That minor difference between the definitions of a trade secret under California and federal law is not pertinent to the proposals in this Article.

10. See Tele-Count Eng'rs, Inc. v. Pac. Tel. \& Tel. Co., 168 Cal. App. 3d 455, 462-465 (1985) (stating requirements for a breach of confidence cause of action).

11. See discussion infra Part II.

12. A 2010 survey of federal courts found that business-to-business trade secret lawsuits were on the increase. See David S. Almeling, Darin W. Snyder, Michael Sapiznikow, Whitney E. McCollum \& Jill Winder, A Statistical Analysis of Trade Secret Litigation in Federal Courts, 45 GonZ. L. REV. 291 (2010). The author of this Article has no reason to believe anything has changed in the decade since. 
circumstances, which body of law should govern? Are California litigants allowed to choose?

Consider Be In, Inc. v. Google, Inc., a 2013 trade secret case where a smaller company claimed that it had met a representative of Google's UK affiliate in London and disclosed ideas for a type of video conferencing platform which could be linked to YouTube. ${ }^{13}$ When Google in the United States later released a video conferencing platform and YouTube offered a link to the platform, the plaintiff brought claims for trade secret misappropriation under California law, copyright infringement, breach of implied contract, and breach of a form nondisclosure agreement. ${ }^{14}$ The plaintiff did not contend that it disclosed any software or actual technology—only ideas. ${ }^{15}$ Google prevailed on a motion to dismiss because the plaintiff failed to allege that anyone in the UK had actually passed its ideas along to the Google or YouTube developers who had created the accused platform and link. ${ }^{16}$ Most important for present purposes is that $B e I n$ is akin to an idea submission lawsuit: One party disclosed its business ideas to a larger counterparty in the hopes of a future deal, and then alleged that its ideas had been misused without compensation under both express and implied contract theories.

Similarly, consider a case that reached the Ninth Circuit in 1976. ${ }^{17}$ An individual submitted a sketch of a backpack design to a sporting goods company and stated his expectation that the idea "will be held in the strictest confidence." 18 The defendant then produced and sold a similar backpack. The plaintiff sued on a trade secret theory, not an idea submission theory. ${ }^{19}$

From the other direction, some idea submission cases read more like trade secret cases, especially where they involve product design ideas rather than film or television scripts. For example, one 1957 idea submission case reads, from a contemporary perspective, like a trade secret case. The plaintiff claimed that he had submitted to a brewery an idea for how to market beer for the "feminine and home consumption trade," and the court allowed, inter alia, a claim for breach of confidence to proceed along the lines of an idea submission dispute. ${ }^{20}$ Yet the case was far afield of the typical context for such a claim. The same is true for idea submission cases that have centered on such ideas as a toy design or a gun holster design. $^{21}$

13. Be In, Inc. v. Google, Inc., No. 12 CV 03373 LHK, 2013 U.S. Dist. LEXIS 147047, at *3-5 (N.D. Cal. Oct. 9, 2013).

14. See id. at *5-6.

15. See id. at *4 ("Be In disclosed its confidential strategies, including a method for integrating [its product] into the YouTube video stream service by way of a button ....").

16. See id. at *11-14. The plaintiff voluntarily dismissed the lawsuit shortly after this ruling.

17. Droeger v. Welsh Sporting Goods Corp., 541 F.2d 790 (9th Cir. 1976).

18. Id. at 791 .

19. Id. at 791-93 (reversing for new trial after jury verdict in favor of plaintiff on trade secret claim, because of erroneous jury instruction).

20. Thompson v. California Brewing Co., 150 Cal. App. 2d 469, 474-76 (1957).

21. See, e.g., Aliotti v. R. Dakin \& Co., 831 F.2d 898, 902 (9th Cir. 1987) (affirming summary judgment for defendant in a case centering on dinosaur toy designs, where the plaintiffs' Desny and breach of confidence claims failed because plaintiff had already publicly disclosed some of the designs, and 
What do we make of cases that fall on the borderline? Could a plaintiff in such cases choose between theories, or might they select one based on ignorance of the other? Would it make any meaningful difference in the average case? Given the overlaps, it is perhaps surprising that few California courts have compared the two. ${ }^{22}$

Indeed, over the decades, vanishingly few cases have considered a Desny claim and a trade secret claim together, side by side. One exception came in 2018, where a plaintiff alleged both a trade secret misappropriation claim and a Desny claim after submitting to the defendant a business plan to "transform the automobile-wrecking industry into a profitable system." 23 The defendant moved to dismiss the Desny claim for breach of an implied-in-fact contract by arguing that it was really a tort claim for breach of an implied-in-law contract and therefore preempted by California's Uniform Trade Secrets Act. ${ }^{24}$ The plaintiff responded by citing an idea submission case to argue that its claim was indeed for implied-in-fact contract. ${ }^{25}$ The court analyzed idea submission case law and determined that because the plaintiff had merely alleged the disclosure of its idea during an "unconsummated business relationship rather than the failure to pay for a product or idea," it would dismiss the claim without reaching the question of CUTSA preemption. ${ }^{26}$ In this instance, then, the trade secret claim carried the day, as the facts underlying the plaintiff's idea submission allegation were deemed an improper fit for the Desny theory.

disclosed them to defendant before seeking a deal to sell them); Ojala v. Bohlin, 178 Cal. App. 2d 292, 301-02 (1960) (affirming judgment in favor of plaintiff in an unfair competition case that was, in actuality, a trade secret case in all but name - albeit one where the court confusingly cited non-California common law misappropriation and trade secret cases without expressly discussing those theories-where the designer of a gun holster had submitted a design for manufacture under contract, then sued when defendant later launched its own, similar design).

22. Indeed, between case law and law review articles, there appears to be only one commentary which has ever given a comparison between idea submission and trade secret law a sustained treatment. In a thorough mapping of patent, copyright, and trade secret preemption against idea submission claims in the nationwide context, Robert Denicola argued in 2014 that modern trade secret law, as defined in the states have adopted the UTSA, should preempt idea submission claims that fall within the ambit of the UTSA preemption standards many states apply. See Robert C. Denicola, The New Law of Ideas, 28 HARV. J.L. \& TECH. 195 (2014). My one quibble with this excellent article is Denicola's concern that California's UTSA preemption test presents "an overly broad scope of displacement" that could prevent unrelated wrongs from being adjudicated. See id. at 206-07. That has not proven to be the case. As detailed in this Article, and especially as to fiduciary duty and duty of loyalty claims, courts applying California law have been adept at parsing causes of action to partially preempt claims in order to preserve tort allegations that are distinct from allegations that the defendant misused nonpublic business information. For an early example of partial trade secret preemption, see E-Smart Techs., Inc. v. Drizin, No. C-06-05528 MHP, 2009 WL 35228, at *7 (N.D. Cal. Jan. 6, 2009), which found an unfair competition claim under section 17200 of the California Business and Professions Code to be partially but not entirely CUTSA-preempted. Separately, Elizabeth Rowe and Sharon Sandeen have noted the potential overlap between trade secret law and idea submission law, noting that the latter likely must proceed exclusively under contract law in states which preempt tort claims under their UTSA enactments. See ElizABEth A. Rowe \& Sharon K. SANDEen, Trade SeCret LaW: CASES AND Materials 168 (2d ed. 2017).

23. Carr v. AutoNation, Inc., No. 2:17-cv-01539-JAM-AC, 2018 U.S. Dist. LEXIS 137566, at *1 (E.D. Cal. Aug. 14, 2018).

24. Id. at *7.

25. Id.

26. Id. at *11-12. 
Another, much earlier decision appears to be the only other reported California case to fully consider trade secret law alongside an idea submission claim. In the 1953 case Taylor v. Metro-Goldwyn-Mayer Studios, the plaintiff brought a plagiarism suit over what it called "painting by light" - an arrangement of lighting and cameras said to produce positive effects in filmmaking. ${ }^{27}$ The plaintiff conceded that California law did not protect bare ideas, but nevertheless, sought protection in what it described as a novel combination of ideas ${ }^{28}$ The plaintiff referred to this purported intellectual property as "know-how," while the defendant called it a "technique and method." 29 For purposes of its motion for summary judgment, the defendant more or less admitted access to the plaintiff's idea and the use of it in a film. ${ }^{30}$ Still, the court rejected the claim, holding that "it does not appear possible for plaintiff to maintain an action based upon an idea, as ideas are not protectable but are as free as the air, to be used by anyone who so desires." 31

The Taylor court granted the defendant's motion, but also made an unusual comparison to trade secret law. ${ }^{32}$ It noted that "[i]t may be plaintiff believes that arrangement of camera and lights and the use of materials was a secret process," but regardless, the plaintiff "disclosed" the information "to the defendant voluntarily," meaning that the "process was thereby thrown into the public domain."33 The court's reference to trade secret law was unusual in the idea submission context, but was perhaps driven by the somewhat technical nature of the claimed intellectual property: techniques for using lighting equipment.

And, in California Brewing - the case involving a marketing idea for beer-the court mused about the contours of a breach of confidence cause of action. ${ }^{34}$ It noted in dicta that "this is, we think, a good deal like some aspects of the law relating to trade secrets," as then set out in the Restatement of Torts. ${ }^{35}$ The court discussed how neither a trade secret claim nor a breach of confidence claim required the existence of a fiduciary duty, but then ended its digression with a confusing (and certainly outdated) statement that a breach of confidence could exist "also where the information is not a trade secret and may be equally a basis for liability." ${ }^{36}$ In short, the court recognized - and even seemed confused by - the overlap between a trade secret claim and the plaintiff's breach of confidence claim, but did not analyze whether, under the facts of the case, they were one and the same.

If common fact patterns exist, is there a meaningful distinction to be made, or is the Desny line of cases based on an antiquated common law theory that should be subsumed within California's Uniform Trade Secrets Act? If there is a basis for

27. Taylor v. Metro-Goldwyn-Mayer Studios, 115 F. Supp. 156, 156-57 (S.D. Cal. 1953).

28. Id. at 157. The plaintiff's concession was driven by then-recent changes in section 980 of the California Civil Code, which had previously allowed claims over certain types of ideas.

29. Id. at 158 .

30. Id.

31. Id. at 159

32. $I d$.

33. Id. at 157 .

34. Thompson v. Cal. Brewing Co., 150 Cal. App. 2d 469, 475-79 (1957).

35. Id. at 475 .

36. Id. at 476 (quoting and discussing RESTATEMENT OF TORTS $§ 757 \mathrm{cmt}$. b (Am. L. Inst. 1939)). 
keeping trade secret and idea submission law separate, where does one draw the boundary, especially outside of classic contexts like employee mobility (for trade secret law) and film script submissions (in Desny cases)? This is the question this Article seeks to answer-but the answer is not black and white.

\section{A HISTORY OF IDEA SUBMISSION AS A CATEGORY OF CALIFORNIA INTELLECTUAL PROPERTY LAW}

From one perspective, trade secret law and idea submission law are two distinct regimes with no conceptual overlap. One balances rights and obligations between employees and employers over what information and knowledge employees can and cannot reuse after a job ends, and does the same for business partners and contractors. The other balances rights and obligations between outsiders who send ideas and the film or other entertainment studios that receive those ideas.

Certainly, the history of the two areas of California intellectual property law would support that distinction. Trade secret law and related employee mobility doctrines, such as the laws of non-competition covenants and invention assignment agreements, have a separate history-one covered reasonably well in the literature. ${ }^{37}$

In summary, the first published California trade secret case is from 1915-a customer list dispute between a former employer and a departing employee, like so many of these early cases. ${ }^{38}$ The first case to find that the information in dispute was not protectable because it was publicly available dates from 1932. ${ }^{39}$ By the 1920s, California courts began using what is now Business and Professions Code section 16600 to nullify post-employment restraints on competition. ${ }^{40}$ In major decisions in 1944 and 1968, the courts declared that an employee's right to change jobs was more important than a former employer's mere fears and concerns over potential trade

37. For background on the history of trade secret law in California and elsewhere, see Graves, supra note 8 (describing the history of trade secret-style cases under California common law up to the 1985 enactment of the CUTSA, as well as related case law under California Business and Professions Code section 16600 back to the 1890s); Ronald J. Gilson, The Legal Infrastructure of High Technology Industrial Districts: Silicon Valley, Route 128, and Covenants Not To Compete, 74 N.Y.U. L. REV. 575 , 594-619 (1999) (detailing the history of the origins and enactment of Business \& Professions Code section 16600 in 1872); Catherine L. Fisk, Working Knowledge: Trade Secrets, Restrictive Covenants in Employment, and the Rise of Corporate Intellectual Property, 1800-1920, 52 HASTINGS L.J. 441, 442, 450 (2001) (describing the nationwide rise of trade secret law in the nineteenth and early twentieth centuries); Sharon K. Sandeen, The Evolution of Trade Secret Law and Why Courts Commit Error when They Do Not Follow the Uniform Trade Secrets Act, 33 HAMLINE. L. REV. 493, 533-35 (2010) (explaining the history of UTSA drafting and noting its intended preemptive sweep).

38. See Empire Steam Laundry v. Lozier, 165 Cal. 95, 96 (1915) (finding customer list to be "a trade secret of great value").

39. See Avocado Sales Co. v. Wyse, 122 Cal. App. 627, 632-34 (1932) (finding customer information to be "readily ascertainable" and thus not secret).

40. See Davis v. Jointless Fire Brick Co., 300 F. 1, 4-5 (9th Cir. 1924) (voiding non-competition clause under what is now section 16600). Another early case, Fortna v. Martin, 158 Cal. App. 2d 634, 638-39 (1958), is notable for finding a post-employment restrictive covenant void to the extent it barred use of information that was not a trade secret. 
secret misappropriation. ${ }^{41}$ And in 1979, the legislature enacted a statute defining the boundaries of employee invention assignment contracts covering certain intellectual property created by employees on and off the job. ${ }^{42}$ California's Uniform Trade Secrets Act became law on January 1, 1985. ${ }^{43}$

Even so, California trade secret law was still nascent in the 1950s when the California Supreme Court issued Desny and other rulings that crafted the rules for idea submission cases that still control today. At that time, trade secrets were a matter of common law, with claims brought under a host of labels; detailed examination of issues ranging from permissible remedies to defenses like reverse engineering still lay in the future. ${ }^{44}$ The typical case involved uncreative information like a customer list in a small-business setting, not the technologies so often at stake in today's Silicon Valley disputes. With their focus on film, television, and Hollywood, idea submission cases in those years may well have seemed more cutting-edge, and more centered on innovation and creativity.

California's idea submission regime was formulated in the 1950s and has remained largely undisturbed since then. It emerged to fill a gap in the law after California's legislature amended, and significantly narrowed, a state statute governing common law copyright protection, Civil Code section $980 .{ }^{45}$ Before 1947, California granted property-like protection to "products of the mind." 46 Under that regime, ideas could be claimed as property rights and litigated without involving contract claims. Thus, many early idea submission cases were litigated under that

41. See Cont'l Car-Na-Var Corp. v. Moseley, 24 Cal. 2d 104, 110 (1944) ("Every individual possesses as a form of property, the right to pursue any calling, business or profession he may choose. A former employee has the right to engage in a competitive business for himself and to enter into competition with his former employer, even for the business of those who had formerly been the customers of his former employer, provided such competition is fairly and legally conducted."); Diodes, Inc. v. Franzen, 260 Cal. App. 2d 244, 255 (1968) ("In the employee situation the courts are concerned not solely with the interests of the competing employers, but also with the employee's interests. The interests of the employee in his own mobility and betterment are deemed paramount to the competitive business interests of the employers, where neither the employee nor his new employer has committed any illegal act accompanying the employment change.")

42. See CAL. LAB. CODE $\S \S 2870-72$ (West 2020).

43. See CAL. CIV. CODE $\S 3426.1-.11$ (West 2020).

44. James Pooley-author of the treatise Trade Secrets, former professor at Berkeley, and the Obama Administration's WIPO representative - notes that by the 1970s, most trade secret cases focused on technology, at least in Northern California. E-mail from James Pooley (June 13, 2020) (on file with author).

45. State law copyright protection was permissible before the 1976 Copyright Act, which now generally preempts state statutes and state tort causes of action that would offer similar protection. See 17 U.S.C. § 301(a) (Copyright Act's preemption clause). For cases explaining how copyright preemption operates to eliminate most overlapping state law tort claims in a circuit that has recently adopted the tests employed by other circuits, see GlobeRanger Corp. v. Software AG United States of Am., Inc., 836 F.3d 477, 485 (5th Cir. 2016) (adopting the "extra element" preemption text used around the country); Ultraflo Corp. v. Pelican Tank Parts, Inc., 845 F.3d 652, 656-57 (5th Cir. 2017) (stating that the broad scope of copyright preemption can include tort claims seeking to create intellectual property out of material that does not meet copyrightability standards).

46. See annotations to CAL. CIV. CODE $\S 980$ for the original, 1872 version. 
statute, when the Desny framework did not yet exist. ${ }^{47}$ It was also not yet clear whether such claims required a showing of novelty. Ultimately, after some ferment in the early 1950s, Desny and its progeny determined that a plaintiff need not demonstrate novelty to prevail on an implied-in-fact contract theory.

The early California cases offered differing bases for idea protection-not just statutory rights under section 980 - and some were not entirely clear about the basis for such protection. At the same time, the basic fact pattern rarely strayed from that of an individual alleging that he or she submitted a script, or other idea for an entertainment production, to a studio or publisher. ${ }^{48}$

For example, the plaintiff in one case sent written material to a comedian for use in film and radio; the defendant responded in writing, stating that he would use the material and asking that the plaintiff send more material "gratis," so that "who knows, both parties being willing, we might enter into a contract." 49 When the defendant did not pay for his admitted use of the plaintiff's material, the court affirmed a jury verdict against him, finding that there was "an express contract, from which a promise to pay respondent for such material, if used by [defendant], could reasonably be implied." ${ }^{\circ 0}$ In response to the defendant's argument that the material was not "protectible" and thus could be used without compensation, the court found - in reliance on section 980, which at that time provided an "exclusive ownership" for the "representation or expression" of "any product of the mind"that the material was "literary property," and affirmed an award of some $\$ 8,000 .{ }^{51}$

In perhaps the most difficult-to-parse early decision, a defendant had agreed through an oral contract, negotiated by agents, to pay for the use of the title of a book about a World War II battle in his film; the court meandered through extensive discussions of contract law, common law copyright, references to copyright and trademark law, and even common law misappropriation, before deciding that a book title was protectable as a property right and affirming judgment in the plaintiff's

47. California Civil Code section 980 was amended again in 1982 to account for the preemptive effect of the revised federal Copyright Act. See CAL CIV. CODE $\$ \S 980-84$ (including annotations for prior versions; current version covers unfixed works of expression, pre-1976 works, and to some degree ownership of inventions and designs). After its major 1947 amendment, section 980 has lived on, though with limited utility and even more limited case law, as a lesser-known category of California intellectual property. See, e.g., Zachary v. Western Pub. Co., 75 Cal. App. 3d 911, 926-27 (1977) (in a curious case arising on a fact pattern that would now be preempted by the federal Copyright Act, reversing summary judgment in the defendant's favor where the plaintiff complained that the defendant had reprinted drawings of a kite design from plaintiff's expired patent); Williams v. Weisser, 273 Cal. App. 2d 726, 744 (1969) (in a common law copyright case involving verbal course lectures at UCLA, affirming judgment in favor of plaintiff, a professor, where defendant ran a business that involved selling transcriptions of lecture notes).

48. See, e.g., Barsha v. Metro-Goldwyn-Mayer, 32 Cal. App. 2d 556, 558-563 (1939) (affirming jury verdict in favor of plaintiff who sent "motion picture scenario" to defendant, which later released a film found to be similar, and where facts referred to (1) an agreement to purchase the manuscript if it were used; and (2) a claim over literary property based on a combination of elements, apparently premised on a tort theory akin to common law copyright).

49. Yadkoe v. Fields, 66 Cal. App. 2d 150, 153-54 (1944).

50. Id. at 158 .

51. Id. at 159-61 (citing CAL. CIV. CODE $\S 980$ ). 
favor. ${ }^{52}$ Another court affirmed a jury verdict against a defendant accused of using the plaintiff's radio program formats without compensation, and did so on a common law copyright claim without reaching the plaintiff's second cause of action for breach of an implied contract. ${ }^{53}$

This doctrinal confusion, as well as the 1947 amendments to section 980 that limited its coverage, brought to a head the need to define what was protectable under state idea submission law, and what theories were available to adjudicate such claims: Express contract? Implied-in-law contract? Implied-in-fact contract? Tort claims such as breach of confidence? A series of decisions culminating in Desny created the special theory of implied-in-fact contract which still governs today, while also allowing for claims based on express contract and tort law. ${ }^{54}$

First, in two decisions released on the same day in 1950, the California Supreme Court wrestled with questions of how a court (and a jury) should determine whether a plaintiff's idea submission was substantially similar to the defendant's subsequent film or other work. ${ }^{55}$ Both disputes featured plaintiffs who clearly had submitted completed works (a radio script and a play) and defendants who had received the works and then released films containing similar content. The court readily concluded that both works were literary property under state law. ${ }^{56}$ In both decisions, the court used the word "idea" to describe the plaintiff's work. ${ }^{57}$ However, neither decision sought to address when and under what conditions the submission of a work creates a contractual duty to pay, as both analyzed the claims under the older version of California's common law copyright statute. ${ }^{58}$

52. The title in question was The Queen of the Flat Tops. See Johnston v. Twentieth Century-Fox Film Corp., 82 Cal. App. 2d 796, 808-815 (1947).

53. See Kovacs v. Mut. Broad. Sys., Inc., 99 Cal. App. 2d 56, $62-66$ (1950) (finding sufficient evidence of access and similarity to affirm jury verdict over work of literary property protected by Civil Code section 980). The California Supreme Court reversed a ruling in favor of a plaintiff on a common law copyright claim in Burtis v. Universal Pictures Co., 40 Cal. 2d 823, 836-37 (1953). There, the court found insufficient similarity between the plaintiff's idea for a film and the defendant's film production.

54. The clearest and most comprehensive guide to idea submission law is Lionel S. Sobel, The Law of Ideas, in 4 Melville B. Nimmer AND DAVID Nimmer, NimMer ON COPYRIGHT § 19D (2019). It helpfully summarizes the 1950 s developments leading to Desny, and the battles over copyright preemption decades later. Still, its scanty reference to trade secret law-despite a lengthy summary of various California common law causes of action and the Copyright Act's preemption of many claims that are also subject to Uniform Trade Secrets Act preemption - underscores the two-ships-passing-in-the-night status of these bodies of law.

55. See Golding v. R.K.O. Pictures, Inc., 35 Cal. 2d 690, 698-99 (1950); Stanley v. Columbia Broad. Sys., Inc., 35 Cal. 2d 653, 660-62 (1950).

56. See Golding, 35 Cal. 2d at 698; Stanley, 35 Cal. 2d at 666-68.

57. See Golding, 35 Cal. 2d at 695 ("claimed original or novel idea"); Stanley, 35 Cal. 2d at 664 ("But when all of these elements are joined to make one idea for a radio program, it is the combination which is new and novel.").

58. One, Stanley, held that submitted works that are novel and concrete can provide for recovery "upon a theory of contract implied in fact or in law," but did not seek to lay out elements for establishing such a claim under a contract theory, and focused instead on the standards under the "common law right [of] literary property" under the pre-amendment version of Civil Code section 980 . $35 \mathrm{Cal} .2 \mathrm{~d}$ at 657 , 660-61. This case is best read as an intermediate stage between that older statute and the Desny ruling. 
In 1953, the court had the opportunity to analyze what causes of action might apply, and why, in an idea submission case decided at the pleading stage. ${ }^{59}$ In Weitzenkorn v. Lesser, the plaintiff sued for breach of express and implied-in-fact contract, implied-in-law contract (a restitutionary theory also called "common count" or "quantum valebant"), and common law copyright ("plagiarism"). ${ }^{60}$ Because the California legislature had amended section 980 to remove protection for ideas not reduced to some form of expression or representation, the court first concluded that an "idea alone, the bare, undeveloped story situation or theme, is not protectible." 61 Finding no similarity between the protectable portions of plaintiff's composition and the defendant's film, the court affirmed the demurrer to the common law plagiarism claim. It also affirmed the rejection of the implied-in-law contract claim for the same reason, holding that "the proof necessary to recover upon the theory of a contract implied in law is the same as that required by the tort action for plagiarism." 62 At the same time, however, the court reversed on the claims for breach of express and implied-in-fact contract, reasoning that protectability of an idea was not an element of such claims, and that "if [defendants] used [plaintiff's idea], or any portion of it, regardless of its originality," liability could arise. ${ }^{63}$ Thus, Weitzenkorn opened the door to a contract theory that did not depend upon a showing that the idea in dispute was novel. ${ }^{64}$

After these decisions set the stage, the California Supreme Court's 1956 decision Desny v. Wilder enunciated the test that is still applied today for implied-in-fact contract claims involving idea submissions. In that case, the plaintiff came up with

59. Notably, in those days the trial court could consider some evidence at the pleading stage, including watching the film at issue in this case.

60. Weitzenkorn v. Lesser, 40 Cal. 2d 778, 780 (1953).

61. Id. at $788-89$.

62. Id. at 795 .

63. Id. at 791-92. The court cited a number of New York cases for the proposition that a valuable idea can be the subject of a valid contract even if it is publicly known. Between Weitzenkorn and Desny, California courts applied the standard of the former in several reported cases. See Kurlan v. Columbia Broad. Sys., Inc., 40 Cal. 2d 799, 810-11 (1953) (reversing a demurrer to five causes of action in a case over a radio script and recording; following Weitzenkorn in holding that, as to a contract claim, "the question of protectibility [sic] need not be considered in determining the sufficiency of the allegations"; finding that trial court could not have fully determined originality for purposes of the plagiarism and implied-in-law contract claims, and could not have fully determined similarity as to all of the claims); Palmer v. Metro-Goldwyn-Mayer Pictures, 119 Cal. App. 2d 456, 460 (1953) (affirming demurrer to an apparent common law copyright claim based on lack of similarity between play and film); Sutton v. Walt Disney Prods., 118 Cal. App. 2d 598, 603 (1953) (affirming demurrer; finding no similarity between book and film for express and implied-in-fact contract claims).

64. Reflecting the ferment, two early articles captured the varying approaches to idea submission claims in California and elsewhere-including express contract, implied-in-fact contract, implied-in-law contract, and tort theories. See Harold C. Havighurst, The Right To Compensation for an Idea, 49 Nw. U. L. REV. 295, 297-98 (1954) (survey of nationwide case law; comparing idea submission claims to trade secret claims in passing and noting then-prevalent view that trade secret law was a species of contract, rather than property, protection); Melville B. Nimmer, The Law of Ideas, 27 S. CAL. L. REV. 119, 124-44 (1954) (survey of nationwide case law, with a critical focus on distinguishing implied-in-law contract claims from implied-in-fact claims and the elements of concreteness and novelty seen in many cases; also offering a brief comparison to trade secret law when covering tort claims for idea submission premised on a "confidential relationship," and asserting that the latter might be based on something described as not "wholly secret but only qualifiedly so"). 
a story based on a real-life 1920s media frenzy over a man trapped in a cave, and telephoned Billy Wilder's assistant in an effort to meet the director. ${ }^{65}$ The assistant asked the plaintiff send a shortened version of the story; then, in a follow-up call, the plaintiff described his synopsis. The plaintiff claimed that he told the assistant that its use was conditioned on payment, and that the assistant told him that if Wilder used the submission, "naturally we will pay you for it." directed a film about a media frenzy over a man trapped in a cave, and the plaintiff claimed it was strikingly similar to his submission. ${ }^{67}$

The court reversed the trial court's grant of summary judgment for Wilder. In doing so, it distinguished the mere disclosure of an idea - which the court was careful to state does not become property simply because it "has cost its producer money and labor, and has a value for which others are willing to pay"-from ideas that are "a subject of contract." 68 Quoting the dissenting opinion in the 1950 case Stanley v. $C B S$, the court stated that even non-novel ideas can be protected by an express agreement. ${ }^{69}$ This is significant because California thus became a jurisdiction where a showing of novelty is not required, at least for this version of an idea submission claim. Then, in the central Desny ruling, the court focused on the circumstances appropriate to an implied-in-fact contract claim, holding that "if the idea purveyor has clearly conditioned his offer to convey the idea upon an obligation to pay for it if it is used by the offeree and the offeree, knowing the condition before he knows the idea, voluntarily accepts the disclosure (necessarily on the specified basis) and finds it valuable and uses it," the law will support the claim. ${ }^{70}$ The case was remanded to the trial court for reconsideration under that contract theory. ${ }^{71}$

In essence, Desny created a narrowly defined claim under an implied-in-fact contract theory —one that (at least) diluted novelty as an element that a plaintiff must establish, but one that also required a plaintiff to demonstrate a close nexus of offer-

65. Desny v. Wilder, 46 Cal. 2d 715, 726 (1956).

66. Id. at 727 .

67. Id. at $727,746 \mathrm{nn} .10-11$. Billy Wilder was an important director with a significant body of work, including the experimental Weimar-era production MENSCHEM AM SONNTAG [PEOPLE ON SUNDAY] (Filmstudio 1930), Double IndEMnity (Paramount Pictures 1944), SunSET BouleVARD (Paramount Pictures 1950), SOME LiKe IT Hot (Ashton Productions 1959), THE APARTMENT (The Mirisch Company 1960), and the Cold War farce ONE, Two, THREE (The Mirisch Company 1961). Fittingly for the landmark case in this area, Wilder's work stands above those in typical idea submission cases, which feature commonplace adventure, thriller, and action storylines. The film at issue in Desny, ACE IN THE HOLE (Paramount Pictures 1951), is a relentlessly cynical take on news-as-entertainment and the public appetite for it, still grim and uncomfortable viewing today. For a recent appreciation, see Vanessa Thorpe, Kirk Douglas: Why His Finest Role was as a Cynical Newspaper Hack, GuARDIAN (Feb. 8, 2020), https://perma.cc/FCL8-VHJ9.

68. Desny, $46 \mathrm{Cal} .2 \mathrm{~d}$ at $731-733$.

69. Id. at 733 .

70. Id. at 739 .

71. Id. at 752. For a then-contemporary take, see Benjamin Kaplan, Further Remarks on Compensation for Ideas in California, 46 CAL. L. REV. 699, 714 (1958) (finding Desny "obscure" but recognizing the court's difficulty in balancing different interests). 
and-acceptance prior to any unconditioned disclosure of the idea. ${ }^{72}$ A 1957 case solidified this direction: "We see no necessity to add the elements of novelty and concreteness to implied-in-fact contracts with reference to authors." ${ }^{.73}$ At the same time, prior public disclosure of the idea would mean that a plaintiff could not proceed with a Desny claim. ${ }^{74}$ One can reasonably conclude that although Desny does not require novelty per se, it comes close by requiring that the plaintiff hold the idea close to their vest, disclosing it only under conditions that give rise to an implied contract to pay for it. ${ }^{75}$

In the more than six decades since, courts still apply the Desny claim elements:

To state a claim for breach of the implied-in-fact contract based on the submission of a screenplay, a plaintiff must allege that: (1) he submitted the screenplay for sale to the defendants; (2) he conditioned the use of the screenplay on payment; (3) the defendants

72. One commentator argues that Desny - via its adoption of Justice Traynor's concurring opinion in Stanley v. $C B S$ - actually adopted something akin to a novelty element for an implied-in-fact contract claim. See William O. Knox, The Role of Novelty in a California Idea Submission Case, 11 UCLA ENT. L. REv. 27, 30 (2004) ("Given the Desny court's adoption of Justice Traynor's Stanley dissent, a nonnovel idea should only be protected where there is an express contract or where the unequivocal conduct of the recipient of the idea makes it clear that - even with full knowledge of the commonplace nature of the idea-he or she nevertheless agrees to pay if the idea is used."). Knox focuses on Justice Traynor's notion that "even though the idea disclosed may be 'widely known and generally understood,' it may be protected by an express contract providing that it will be paid for regardless of its lack of novelty." See $i d$. (citing Desny, $46 \mathrm{Cal} .2 \mathrm{~d}$ at 733 (quoting Stanley dissent)). Knox also includes a line from that dissent not quoted in Desny - "If the idea is not novel, the evidence must establish that the promisor agreed expressly or impliedly to pay for the idea whether or not it was novel" - to conclude that California law requires novelty (or something close to it) for these types of claims. Id. (quoting Stanley v. Columbia Broad. Sys., 221 P.2d 73, 85-86 (Cal. 1950) (Traynor, J., dissenting)). As much as I too would favor a robust novelty requirement, however, the language Knox relies on does not support the strong reading he gives it. It might be read to say that there can be no implied-in-fact contract for a non-novel idea unless the defendant realized the idea was not novel but agreed to pay anyway. But that reading requires adding a logical step. The quoted language is more easily read to say that there can be a valid implied-in-fact contract claim where the defendant impliedly agreed to pay, regardless of whether anyone stopped to consider whether the idea possessed novelty.

73. See Chandler v. Roach, 156 Cal. App. 2d 435, 438, 444 (1957) (in case where plaintiff claimed an idea submission for a show focusing on a public defender's office, reversing judgment where jury instruction on Desny claim included "the requirement of novelty and that of concreteness," reasoning: "We see no reason to impose blindly and automatically upon the implied-in-fact contract the elements which may be necessary to establish a property right."); see also Gunther-Wahl Prod., Inc. v. Mattel, Inc., $104 \mathrm{Cal}$. App. 4th 27, 35 (2002) ("[A]n agreement to disclose an abstract idea may be compensable, even though it lacks novelty.").

74. See Quirk v. Sony Pictures Ent., Inc., No. C 11-3773 RS, 2013 U.S. Dist. LEXIS 47954, at *13, *28-35 (N.D. Cal. Apr. 2, 2013) (granting summary judgment for defendants on several grounds, including that the plaintiff had publicly disclosed his ideas in a novel years before the release of the accused film, and thus had no basis to pursue a Desny claim); Jonathan Browning, Inc. v. Venetian Casino Resort, LLC, No. C 07-3983 JSW, 2007 U.S. Dist. LEXIS 95440, at *20-24 (N.D. Cal. Dec. 18, 2007) (granting motion to dismiss in part, including as to implied-in-fact contract claim, where plaintiff accused defendant of unauthorized reproduction and display of lighting fixtures; finding that plaintiff failed to state a Desny claim because its "design ideas had been conveyed to [defendant] and to the general public prior to submitting its bid to [the defendant]").

75. As James Pooley has noted, Desny also stated that the bare public facts - including the real-life cave rescue effort-alone were not protectable. Email from James Pooley, June 13, 2020 (on file with author). See Desny, 46 Cal.2d at 750 ("The plaintiff can have no property right in the public domain facts concerning Floyd Collins or in the abstract idea of making a photoplay dramatizing those facts."). 
knew or should have known of the condition; (4) the defendants voluntarily accepted the screenplay; (5) the defendants actually used the screenplay; and (6) the screenplay had value. 76

Over the years, there have been a significant number of cases which focus on the second, third, and fourth elements - the circumstances surrounding the manner in which the defendant received the plaintiff's submission. ${ }^{77}$

76. Jordan-Benel v. Universal City Studios, Inc., 859 F.3d 1184, 1191 (9th Cir. 2017).

77. See Daniels v. Walt Disney Co., 958 F.3d 767, 770-75 (9th Cir. 2020) (affirming dismissal of "boiler-plate" Desny claim where plaintiff alleged conversations about animated characters with studio but neither facts of an express payment offer by defendant nor that the idea disclosure was made under circumstances that fit the Desny claim elements); Reilly v. Wozniak, No. CV-18-03775-PHX-MTL, 2020 U.S. Dist. LEXIS 36256, at *25-30 (D. Ariz. Mar. 3, 2020) (denying motion to dismiss Desny claim under California law where plaintiff alleged that he offered for sale the idea of using the defendant's name and likeness to start on online school and introduced the defendant to a potential business partner, and there was agreement to proceed); Alexander v. MGM Studios, Inc., CV 17-3123-RSWL-KSx, 2017 U.S. Dist. LEXIS 214497, at*21 (C.D. Cal. Aug. 14, 2017) (dismissing Desny claim with prejudice where plaintiff tweeted and disclosed his film idea to defendants or those working with them, but did so inconsistent with an offer for sale); Merino v. Cool Gear Int'1, Inc., 3:16-cv-01192-BEN-BGS, 2017 U.S. Dist. LEXIS 9170, at *10 (S.D. Cal. Jan. 19, 2017) (dismissing Desny claim where plaintiff alleged that it disclosed a series of marketing ideas for a patented straw to defendant, because plaintiff failed to plead the "third element"that defendant accepted the submission on the condition that it would pay for any use); Reed v. Nat'l Football League, CV 15-1796 DMG (AGRx), 2015 U.S. Dist. LEXIS 190110, at *4-6 (C.D. Cal. Dec. $18,2015)$ (dismissing claims including breach of implied-in-fact contract and breach of confidence where plaintiff alleged that he left a voicemail with the NFL disclosing an idea for a television series, but failed to plead either an expectation of payment, as to the Desny claim, or an obligation of confidentiality, as to the breach of confidence claim); Gem \& I Prods., Inc. v. Disney Consumer Prods., Inc., SACV 10-1051 AG (RNBx), 2011 U.S. Dist. LEXIS 163319, at*13-14 (C.D. Cal. Jan. 11, 2011) (denying motion to dismiss a Desny claim, among others, where plaintiff alleged that it disclosed a sleeping bag design idea to defendants with expectation of payment); A Slice of Pie Prods., LLC v. Wayans Bros. Ent., 487 F. Supp. 2d 41, 51-52 (D. Conn. 2007) (applying California law and granting summary judgment to defendants where plaintiff alleged Desny claim over screenplay submission, based on findings that there was no bilateral expectation of compensation and defendants did not use plaintiff's idea submission); Gunther-Wahl Prods., Inc. v. Mattel, Inc., 104 Cal. App. 4th 27, 42-43 (2002) (reversing jury verdict for defendant on Desny claim where trial court erroneously instructed jury that plaintiffs "clearly conditioned" disclosure of animated character ideas, which "could easily" cause the jury "to require an express oral or written representation of compensation, which the law does not require for an implied contract"); Landsberg v. Scrabble Crossword Game Players, Inc. (Landsberg I), 736 F.2d 485, 489-90 (9th Cir. 1984) (where plaintiff disclosed his manuscript for a game-playing strategy to maker of popular board game, and where defendant was accused of commissioning a work that was based on the plaintiff's manuscript, remanding on state law Desny claim to determine whether defendant received plaintiff's first submission in confidence, such that it could have been bound to pay when it requested a second copy of the manuscript); Landsberg v. Scrabble Crossword Game Players (Landsberg II), 802 F.2d 1193, 1196-97 (9th Cir. 1986) (in second appellate ruling in this case, affirming judgment in plaintiff's favor on Desny claim, where trial court found that plaintiff had submitted the idea with expectation of payment if defendant used it commercially, and that defendant had understood that condition when it published plaintiff's board-game strategy manuscript); Whitfield v. Lear, 751 F.2d 90, 93-94 (2nd Cir. 1984) (applying California law where plaintiff sent a "mailgram" to a studio, followed by a script for a television show, and assistant stated that recipient was not interested but that the "mailgram" had been forwarded to a company vice president; finding that this was sufficient to defeat defendant's summary judgment motion as to the formation of an implied contract under Desny); Faris v. Enberg, 97 Cal. App. 3d 309, 316-324 (1979) (where plaintiff had idea for quiz show and intended to produce it himself, affirming summary judgment in favor of defendant - a candidate for an announcer on the show-where there was neither an 
A similarly large number of cases have analyzed whether or not the defendant actually made use of the plaintiff's submission, ${ }^{78}$ while other cases involve the treatment of downstream recipients - those who never met with the plaintiff but may have received the submission indirectly from another person or entity. ${ }^{79}$

expectation of payment nor obligation to pay, thus dooming the Desny claim); Blaustein v. Burton, 9 Cal. App. 3d 161, 184 (1970) (reversing summary judgment in defendants' favor, on plaintiff's apparent claims of breach of oral and implied contracts and breach of confidence; remanding for fact-finding on whether an agreement was formed when producer met agent for stars and proposed a specific film adaption of a Shakespeare play); Minniear v. Tors, 266 Cal. App. 2d 495, 504 (1968) (where plaintiff created pilot film for underwater diving concept, reversing judgment in defendant's favor on implied-in-fact contract claim on finding that plaintiff could have satisfied Desny elements and that idea need not be protectable as property; affirming nonsuit as to conversion and fraud claims in absence of showing that plaintiff had a property interest in the idea); Davies v. Krasna, 245 Cal. App. 2d 535, 549 (1966) (affirming finding of implied-in-fact contract claim on promise-to-pay element, where plaintiff claimed to have submitted story idea for a film and defendant's agent accepted the submission with awareness of plaintiff's expectation of payment); Thompson v. California Brewing Co., 150 Cal. App. 2d 469, 473 (1957) (in case involving idea for beer marketing concepts, reversing demurrer on claims for breach of oral contract, breach of impliedin-fact contract, and breach of confidence, noting that the "promise to pay" element of the Desny claim "could also be proved by conduct," and allowing case to proceed to see whether plaintiff could prove that element).

78. See Benay v. Warner Bros. Ent., Inc., 607 F.3d 620, 629-32, 634 (9th Cir. 2010) (reversing judgment in defendants' favor on Desny claim because, while lower court correctly found lack of substantial similarity for federal copyright purposes, court had erred in treating standard for use under Desny claim as identical to that for the copyright claim); Klekas v. EMI Films, Inc., 150 Cal. App. 3d 1102, 1114-15 (1984) (affirming summary judgment for defendants, including as to an implied-incontract claim, where plaintiff claimed that his novel was the basis of defendants' film, but finding that defendants did not use plaintiff's ideas); Fink v. Goodson-Todman Enters., 9 Cal. App. 3d 996, 10081009,1008 n.16, 1013, 1016 (1970) (where plaintiff had submitted idea for television series, reversing judgment in defendant's favor on implied-in-fact contract claim and several other causes of action; finding substantial similarity in defendants' production and explaining that a Desny claim need not involve protectable content); Henried v. Four Star Television, 266 Cal. App. 2d 435, 436-37 (1968) (affirming judgment at demurrer stage where plaintiff submitted an idea for a television series and then filed suit under claims including implied-in-fact contract and "violation of a confidential relationship," where "[t]he only point of similarity" in the defendant's production was a common symbol of wealth); Ware v. Columbia Broad. Sys., Inc., 253 Cal. App. 2d 489, 494-96 (1967) (in case where plaintiff submitted a play to defendant for sale and defendant did not purchase it, rejecting plaintiff's primary, plagiarism cause of action because defendant's play was not substantially similar; also rejecting Desny and other contract claims because plaintiff had not clearly alleged a Desny-style theory that he had offered a "public domain story idea" to the defendant).

79. See Quirk v. Sony Pictures Ent., Inc., No. C 11-3773 RS, 2012 U.S. Dist. LEXIS 107362, at *8-12 (N.D. Cal. July 5, 2012) (denying motion to dismiss on Desny claim as to defendants who were not direct recipients of plaintiffs' novel, but also rejecting plaintiff's position that he need only "trace" a copy of his book to a defendant); see also Quirk v. Sony Pictures Ent., Inc., No. C 11-3773 RS, 2013 U.S. Dist. LEXIS 47954, at *1-3, *28-32 (N.D. Cal. Apr. 2, 2013) (granting summary judgment for defendants on Desny claim where plaintiff had speculated that Sony had somehow obtained screenplays from a different studio; the claim failed because among other things, plaintiff had publicly disclosed his ideas in a novel years before the release of the accused film, and thus had no basis to pursue such a claim); Benay v. Warner Bros. Ent., Inc., CV 05-8508 PSG (FMO), 2012 U.S. Dist. LEXIS 183791, at *18-25 (C.D. Cal. Feb. 14, 2012) (granting summary judgment to some defendants on Desny claim because of their lack of privity with recipients of plaintiffs' screenplay submission); Green v. Schwarzenegger, CV 93-5893WMB, 1995 U.S. Dist. LEXIS 14031, at*17-19 (C.D. Cal. July 17, 1995) (granting summary judgment for defendants on implied-in-fact contract and breach of confidence claims where plaintiffs alleged submission of screenplay for film idea, but defendants were not the parties who received it; court went 


\section{SHOULD CALIFORNIA'S TRADE SECRET AND IDEA SUBMISSION REGIMES BE MERGED?}

With this background, and facing a clear subject matter overlap in many cases, we arrive at the primary question: Should California's idea submission and trade secret cases be merged into a single body of state intellectual property law, or are there insurmountable differences that keep them separate, in whole or in part?

One might wonder why a question of merger should be raised at all. The answer lies, in part, with the danger that uncertain and unpredictable IP regimes pose for a broad and robust public domain of information, available for the benefit of all. When litigants can bring tort claims with loose boundaries and uncertain standards in order to claim IP-related protection for any information they wish to stop another from using, the robust public domain is at risk. More power shifts to attorneys, who can manipulate the system by pulling together any number of tort claims, resulting in a legal system that is too unpredictable for creators to take full advantage of information that is in fact available to them. A merger of these ambiguous doctrines would close gaps that weaken protection of the public domain, and would render protectable only that which the legislature or the state supreme court has blessedor that which is the subject of a negotiated contract.

Why this question has not arisen more often may be a question for a sociologist of the legal profession-whether it is due to different industries, different sets of attorneys, little or no shared discussion at law school symposia and conferences, or simply gaps in local vernacular and everyday practitioner know-how between Northern and Southern California. But these potential accidents of culture and geography only invite the question whether California courts are applying inconsistent principles to substantially identical problems.

Consistent with this gap, the commentary has generally focused on intra-regime questions, rather than inter-regime comparisons. For idea submission law, most of the law review articles after the early, seminal writings in the 1950s have offered general summaries, ${ }^{80}$ or policy proposals for modifying elements of an implied-infact contract cause of action, among others-including whether to strengthen the hand of a plaintiff in such cases, ${ }^{81}$ or to make such claims more difficult to

through lengthy analysis of non-use as well); Rokos v. Peck, 182 Cal. App. 3d 604, 613-19 (1986) (affirming a nonsuit in defendant's favor, where plaintiff alleged claims for implied-in-fact contract and breach of confidence; plaintiff had a contract with a writer involving an idea for a film script, but could not bring claims against downstream recipients of the idea with whom she had no contract or relationship of confidentiality).

80. See generally Joseph J. Siprut, Are Ideas Really Free as the Air? Recent Developments in the Law of Ideas, 51 IDEA 111, 126-27 (2011) (general summary of idea submission cases); Lisa Pearson, Navigating the Bramble Bush in Idea Submission Cases, 4 J. MARSHALl ReV. INTELL. PrOP. L. 36 (2004) (practitioner's guide to common litigation issues in idea submission cases).

81. See K.J. Greene, Idea Theft: Frivolous Copyright-Lite Claims, or Hollywood Business Model?, 7 HASTINGS SCI. \& TECH. L.J. 119, 121-23, 141 (2015) (calling for federalization of idea submission claims to reduce inconsistent approaches among the states, which would strengthen such claims' ability to "protect the least advantaged," as the "dysfunctional state of "idea law' .. punishes the folks at the bottom, while enriching institutional elites"); David M. McGovern, What Is Your Pitch?: Idea Protection 
establish. ${ }^{82}$ Very little looks outward to trade secret law, and comparisons of the two regimes have been infrequent. ${ }^{83}$ The following discussion identifies two areas where such comparison proves fruitful.

\section{A. BORROWING FROM INDEPENDENT DEVELOPMENT TO BRING INDEPENDENT DERIVATION OUT OF THE SHADOWS}

We first examine an area of subject matter overlap where courts can seamlessly integrate important insights from the idea submission cases into trade secret law to improve the quality of analysis in the latter.

Perhaps the most intriguing possibility in merging California's trade secret and idea submission law is the opportunity it offers to better define the defense of independent derivation. Broadly speaking, independent derivation is a defense to a

Is Nothing but Curveballs, 15 LOY. L.A. ENT. L.J. 475, 478-79, 507-08 (1995) (providing high-level summary of different theories of protection for idea submissions and calling for a uniform standard that would "recogniz[e] the need for quasi-contract protection of ideas and ... remov[e] the burdensome prerequisites of novelty and concreteness").

82. See Brian Casido, Note, Benay v. Warner Bros. Entertainment, Inc.: New Standard Needed for Determining Actual Use, 41 Golden GATE U. L. Rev. 327, 338, 345-47 (2011) (proposing that, for implied-in-fact contract claims under California law, the standard for establishing similarity be heightened, akin to that seen in copyright claims, to avoid decisions premised on unprotectable elements); Kelly Rem, Note, Idea Protection in California: Are Writers Too Readily Compensated for Their Screenplays?, 28 HASTINGS COMMC'N \& ENT. L.J. 333, 346-47 (2006) (proposing a higher bar for determining similarity between idea submission and the accused work in implied-in-fact-contract cases, such that plaintiff be "required to show the existence of some common element beyond the mere subject matter of the works," meaning that "some of the same or similar elements in [the plaintiff's] story were also in the film created by the studio," and arguing more generally that ideas should not be protectable "unless [the idea] has some form of embodiment to actually protect"); William O. Knox, The Role of Novelty in a California Idea Submission Case, 11 UCLA ENT. L. REv. 27, 30-33 (2004) (arguing that California courts since the 1950s have misread Desny and other foundational decisions and have incorrectly ruled that novelty is not required to establish an idea submission claim for breach of impliedin-fact contract; proposing that novelty be recognized as a requirement); Mary LaFrance, Something Borrowed, Something New: The Changing Role of Novelty in Idea Protection Law, 34 SETON HALl L. REV. 485, 509-511 (2004) (contrasting the treatment of whether novelty is required to state a contractbased idea submission claim in New York, New Jersey, and California and advocating for a Californiastyle approach where novelty is not a requirement, but can be useful evidence of value or of "the buyer's possession of the same idea at the time of disclosure"); Brian Devine, Free as the Air: Rethinking the Law of Story Ideas, 24 HASTINGS COMMC'N \& ENT. L.J. 355, 386-91 (2002) (proposing, on the one hand, that Desny claims imply a promise to pay when producers accept an idea submission "not covered by a release," but also advocating that for implied-in-fact contract claims, novelty be made an element of the claim, and that such novelty "should turn on the level of detail in the submission").

83. For a notable exception, see Denicola, supra note 22. See also Arthur R. Miller, Common Law Protection for Products of the Mind: An "Idea" Whose Time Has Come, 119 HARV. L. REV. 703, 735$38,778-79$ (2006) (a wide-ranging essay that proposes eliminating "concreteness and novelty" as a requirement for some forms of idea submission claims and arguing that such claims survive copyright preemption; the article purports to survey intellectual property law but its treatment of trade secret law is thin and, among other things, does not consider the potential effect of statutory trade secret preemption on the types of claims the author envisions); Greene, supra note 81, at 130 ("Trade secret law is not generally helpful in the idea submission context ... [because] new entrants cannot obtain agreements from studios and networks to maintain confidentiality or nondisclosure of their ideas. Indeed, far from securing nondisclosure agreements, new entrants are typically forced to sign standard form contracts that release studios from legal liability for idea misappropriation.”). 
claim for wrongdoing where - even if the plaintiff has a valid right in a trade secret or an idea, and even if the defendant received that information from the plaintiffthe defendant is not liable because it independently conceived the same (or similar) information without reliance on what it obtained from the plaintiff. In other words, the origin of the defendant's challenged media production, technology, or development lies not in the plaintiff's information, but in a different source altogether. ${ }^{84}$ Independent derivation, then, is a critical component of trade secret law.

Unlike patent law, a trade secret claimant does not have rights against the world. It only has rights against those with whom it had some privity or contact (ranging from an employee to an unauthorized hacker), and others who have wrongfully acquired, used, or disclosed the claimant's trade secret with the required level of intent. ${ }^{85}$ Absent misappropriation, anyone can create the exact same information, and hold it as a trade secret in the same manner-meaning that two or more entities can own the same information as a trade secret, at the same time - or can publicly disclose it, extinguishing the rights of anyone else holding it as a trade secret, without liability for doing so. Thus, independent derivation is a cornerstone of the limitations placed on the reach of trade secret law, and its articulation is important to maintaining such limits.

In trade secret cases, defendants frequently assert the independent derivation defense, but there is surprisingly little guidance in the published case law. Also, there is almost no academic commentary on the subject. ${ }^{86}$ In great contrast, however, California's idea submission cases have created a well-developed body of analysis for weighing a defendant's evidence for the strikingly similar defense of independent development (sometimes called "independent creation").

\section{Independent Derivation in California Trade Secret Law}

Independent derivation is a defense to a trade secret claim in every jurisdiction, but California's legislature - alone among the states that adopted the Uniform Trade

84. This is my own definition. Fulsome definitions of independent derivation in trade secret case law and treatises are sparse. James Pooley, in his often-cited treatise, describes the concept as follows: "To be 'independent' in this context, acquisition of the secret must not be derived from knowledge gained in confidence, directly or indirectly, from the secret's owner, or from knowledge gained by espionage." JAMES POOLEY, TRADE SECRETS § 5.01[1][b] (2020).

85. See CAL. Civ. Code $§ 3426.1$ (b) (West 2020) (definitions of "misappropriation"). Privity means a direct relationship, such as employment or a business partnership, but it can also reach hackers or others who make contact with the claimant's computer systems in order to wrongfully take trade secrets. Also, those downstream who acquire or learn the trade secret with actual or constructive notice that it belongs to someone else can be liable. See id.; PMC, Inc. v. Kadisha, 78 Cal. App. 4th 1368, 1382 (2000) ("Misappropriation of trade secrets is an intentional tort.")

86. By contrast, reverse engineering — another defense where a defendant shows that it obtained information lawfully even if the plaintiff had a valid trade secret-has seen in-depth commentary. See, e.g., Pamela Samuelson \& Suzanne Scotchmer, The Law and Economics of Reverse Engineering, 111 YALE L.J. 1575 (2002). Similarly, the vexing question of whether a defendant has used the plaintiff's trade secret in its product or technology is the subject of a thorough recent treatment. See Joseph P. Fishman \& Deepa Varadarajan, Similar Secrets, 167 U. PA. L. REV. 1051 (2019). Independent derivation, however, is a distinct question. 
Secrets Act-added explicit language to the model statute, providing that "independent derivation," in and of itself, is not "improper means" and thus cannot constitute trade secret misappropriation. ${ }^{87}$ Congress included similar language when enacting the Defend Trade Secrets Act in 2016. Defendants facing state and federal trade secret cases in California potentially can assert this defense, if the facts so warrant. $^{88}$

In the only major California decision interpreting this language of the state's enactment, a court held that although a defendant bears the burden of producing evidence of independent derivation if the plaintiff first establishes a prima facie case of misappropriation, independent derivation is not an affirmative defense. ${ }^{89}$ That is, once the defendant satisfies the intermediate burden of coming forward with evidence of independent derivation, the burden of proof remains with the plaintiff to establish that the defendant's product or technology was the result of misappropriation and not independent effort. ${ }^{90}$ Few California trade secret decisions since then have delved into the independent derivation defense-much less offered an organized methodology for assessing the type and quality of the evidence a

87. See CAL. CIV. CODE § 3426.1(a) ("Reverse engineering or independent derivation alone shall not be considered improper means."). The legislative history does not pinpoint the exact reasoning for adding this sentence to the statute (in contrast to a great deal of commentary about other changes, such as removing the "readily ascertainable" language seen in the model UTSA), but the change can be seen in California State Senate documents from August 1984. As James Pooley has noted, and as the Sargent Fletcher case discussed below notes, the concept is most properly defined as a "traverse" rather than a "defense." See Sargent Fletcher, Inc. v. Able Corp., 110 Cal. App. 4th 1658, 1670 (2003). This Article uses "defense" for plain-language reasons only; this usage does not mean "affirmative defense," where the defendant bears the burden of proof.

88. See 18 U.S.C. $\S 1839(6)(B)$ (“[T]he term 'improper means' ... does not include reverse engineering, independent derivation, or any other lawful means of acquisition."). The author does not mean to suggest that defendants in other jurisdictions cannot assert the defense — only that California's legislature made that invitation clear. The model UTSA includes a reference to independent derivation in its commentary. See Unif. L. Comm'n, Prefatory Note to Uniform Trade SeCrets ACt with 1985 AMENDMENTS 1, 2 (1985) (citing a 1975 case for the proposition that "prior, independent discovery [is] a complete defense to liability for misappropriation"), https://perma.cc/U7YL-JPQL.

89. See Sargent Fletcher, Inc., 110 Cal. App. 4th at 1668-70.

90. Id. at 1663-64, 1670. The jury sided with the defendant, which presented evidence of both independent derivation and reverse engineering. Because only the burden of proof was at issue, the appellate court did not provide details about the nature of the defense, such as whether the defendant contended that it independently created its own design for the airplane refueling system which comprised the claimed trade secrets, obtained a design from a third party, or otherwise obtained the same information. Notably, Sargent Fletcher did not cite any of California's idea submission cases addressing the defense of independent creation; it cited one pre-CUTSA Ninth Circuit trade secret case and one then-recent Third Circuit trade secret case under Pennsylvania law. See id. at 1669 (citing Droeger v. Welsh Sporting Goods Corp., 541 F.2d 790, 792-93 (9th Cir. 1976) (reversing jury verdict of trade secret misappropriation against defendant where plaintiff had submitted backpack design in confidence to one of defendant's employees; company was deprived of defense of "subsequent independent invention," based on claim that the employee did not tell others and that others at the defendant independently created the accused backpack design, because trial court incorrectly imputed the employee's knowledge to the company); Moore v. Kulicke \& Soffa Indus. Inc., 318 F.3d 561, 565, 573-74 (3d Cir. 2003) (affirming a jury verdict for trade secret defendant, in a ruling much like Sargent Fletcher, where defendant had argued independent development of the allegedly secret "technique"; finding that independent development is not an affirmative defense). 
defendant brings forward..$^{91}$ And, around the country, trade secret cases analyzing a defendant's claim of independent derivation are also few and far between. ${ }^{92}$

The problem with this limited case law is that it does not offer a formal methodology for understanding what types of independent derivation evidence a defendant might offer, and how to weigh such evidence. For example, some cases have made passing mention of independent derivation in reference to the defendant's possession of the same information before first meeting the plaintiff. (I label this "preexisting knowledge," though no court has adopted that terminology.) But no cases have expressly discussed that temporal aspect of the defense or analyzed it in detail. $^{93}$ Indeed, notwithstanding the importance of the independent derivation defense in litigation, the courts have not organized it into discrete categories for analysis - identifying, for example, defenses based on temporal circumstances (that is, the time when the defendant claims to have obtained or conceived the independent information) or on the identity of the sources of independent information (that is, whether the defendant claims to have self-developed the information, or instead obtained it from others).

91. See, e.g., Masimo Corp. v. Sotera Wireless, Inc. (In re Sotera Wireless, Inc.), 591 B.R. 453, 461, 463-64 (S.D. Cal. Sept. 11, 2018) (affirming Bankruptcy Court ruling that defendant had independently derived two aspects of products relating to thresholds for patient alarms used at hospitals, where defendant's employees offered credible testimony that an employee hired from the plaintiff, and thus exposed to plaintiff's information, had not disclosed it to them, that they had carried out extensive research on patient data to develop their ideas, and - in at least one case - that they had begun work on their idea before defendant hired an employee from plaintiff); Brocade Commc'ns Sys., Inc. v. A10 Networks, Inc., No.: C 10-3428 PSG, 2013 U.S. Dist. LEXIS 8113, at *68, *68 n.191 (N.D. Cal. Jan. 17, 2013) (noting the burden of proof under Sargent Fletcher regarding independent derivation where jury found that defendant had misused the claimed trade secrets).

92. This assertion is based on extensive Lexis and Westlaw database searches using a variety of search terms, a review of four treatises on trade secret law, and previous research efforts during litigations. In one notable case from the District of New Jersey, the court found that the plaintiff's trade secret claim should be "properly re-characterized as a submission-of-idea claim," and found that the defendant had independently developed its design for a toy water gun. See Ahlert v. Hasbro, Inc., 325 F. Supp. 2d 509, 513, 515 (D.N.J. 2004). In Ahlert, the plaintiff's agent had submitted a toy product idea to one of the defendants, a toy gun company. Id. at 511 . When it later launched a similar product, the plaintiff sued for trade secret misappropriation. The court applied pre-UTSA New Jersey law which, due to Restatement-era definitions of "use," did not apply to ideas that the plaintiff itself did not put to use. $I d$. at 513. The court thus characterized the case as an idea submission lawsuit and found "convincing documentation" that the defendants had developed their product independently and without the personnel who had access to plaintiff's submission. Id. at 513-15. Ahlert is thus a case of post-disclosure independent derivation by different people at the same company.

93. See generally FLIR Sys., Inc. v. Parrish, 174 Cal. App. 4th 1270, 1274, 1276 (2009) (affirming attorneys' fees award after bench trial against plaintiff for "bad faith" trade secret allegations, noting that defendants' "business plan" had been developed by one of them "in 1998 and 1999 when he was selfemployed," before defendants worked for plaintiff, and that trial court found that the plan did not misappropriate plaintiff's trade secrets); Rigging Int'1 Maint. Co. v. Gwin, 128 Cal. App. 3d 594, 613-14 (1982) (affirming bench trial ruling in favor of defendant, a former employee of plaintiff, on claims including breach of a nondisclosure agreement; in somewhat confusing ruling, court noted that, as to claimed trade secrets in a "twist-lock interlock system," defendant had been "well aware" of inadequacies in interlock systems before joining plaintiff, he had been turned down when he approached his employer about improving an interlock system, so he created the improvements while "on vacation" and also after leaving plaintiff). 
To help build a methodology that would take account of these factors, we turn to California case law on the "independent development" defense asserted in its idea submission cases.

\section{Independent Development in California Idea Submission Law}

In contrast to the paucity of case law addressing independent derivation in the trade secret context, there is a robust body of independent development case law in the idea submission context - where the defense is virtually identical to its trade secret cousin. In contrast to the trade secret cases on independent derivation, these decisions offer detailed, lively discussions of the types of evidence that defendants put forward, and what courts find useful when assessing whether the defendant independently created the same or similar information comprising the plaintiff's idea.

To be sure, these cases do not explicitly outline the methodology this Article proposes. But in totality, they offer a means to organize the defense of independent derivation by (1) a temporal element - that is, whether the defendant claims that such derivation took place before or after the accused individual learned or acquired the trade secret from the plaintiff; and (2) the source of the claimed independent derivation - that is, whether the idea came from (a) the accused individual, (b) his or her coworkers, or (c) a third party. When considering every combination of these two elements, six different possibilities for independent derivation arise, some of which - by their very nature - may require stronger evidence than others.

Indeed, under the Desny elements for breach of implied-in-fact contract, a defendant in an idea submission case can defeat the use element by showing independent development of the same or similar information. The concept is not new: A 1949 enactment of California's common law copyright statute- the predecessor to the Desny claim — reflects an early version of it. ${ }^{94}$ Still, scholarly commentary has been sparse, ${ }^{95}$ and treatises do not dwell on this defense. ${ }^{96}$

Nonetheless, California's idea submission case law is well developed in this area, and it demonstrates how courts can subdivide the independent development concept into different temporal circumstances and different sources of the independently developed information.

94. See CAL. CIV. CODE $\S 984$ (West 2020) (enacted in 1949) ("If the owner of an invention or design does not make it public, any other person subsequently and originally producing the same thing has the same right therein as the prior inventor, which is exclusive to the same extent against all persons except the prior inventor, or those claiming under him.").

95. One student note criticizes California's treatment of the independent development defense in idea submission cases, but in the uncommon scenario where the defendant enters into two contracts for the exact same idea, and thus fails to pay one party by arguing that the source of the idea came only from the second party, and not from the plaintiff as well. See Jonathan Richard Sandler, Note, Idea Theft and Independent Creation: A Recipe for Evading Contractual Obligations, 45 LOY. L.A. L. REV. 1421, 1424, $1450-51$ (2012).

96. E.g., NiMMER ON COPYRIGHT, supra note 54, § 19D.07[C][2] (two-page section on "Rebutting Inference of Actual Use-Independent Creation"). 
The independent development concept first appeared in a published case in the $1930 \mathrm{~s},{ }^{97}$ and the first court to analyze it did so in the late 1950s. That case, Teich $v$. General Mills, Inc., featured pre-existing knowledge obtained from a third party. ${ }^{98}$ In July 1955, the plaintiff contacted a division of the defendant company, and then submitted a "sun picture" camera kit for children. The recipient showed interest. ${ }^{99}$ The main division of defendant company subsequently released a similar toy. At trial, on the plaintiff's Desny claim the jury found an inference of use from the fact of access and awarded damages. ${ }^{100}$ The trial judge, however, reversed the judgment on a post-trial motion because the defendant had shown that, in May 1955, a thirdparty firm had submitted an idea for a similar children's toy; the general concept was publicly known, so both submissions were merely variants of a known idea. ${ }^{101}$ The appellate court, in affirming, framed the question as such: "[D]oes proof that there was no copying of plaintiff's product make a complete defense, although the thing actually used by defendant was closely similar to the one which plaintiff had presented to it? The authorities require an affirmative answer." 102

Another example of independent development through third-party informationacquired both before and after the plaintiff's submission - came several decades later. In the 2007 case, Hollywood Screentest of America v. NBC Universal, the court affirmed summary judgment for the defendants on a Desny claim. ${ }^{103}$ The plaintiff claimed that in 2001, he had submitted ideas to NBC for a reality television contest show. ${ }^{104}$ The trial court, however, found undisputed and extensive evidence that, starting in 2001, three third parties had created ideas for virtually the same accused television show, and submitted them to NBC in 2002. ${ }^{105}$ The appellate court cited Teich for the proposition that an "inference of use could be dispelled as a matter of law by direct evidence of independent creation," and rejected the plaintiff's evidence-free "speculation" as to use of his ideas. ${ }^{106}$

Another early decision, Donahue v. Ziv Television Programs, wrestled with a more difficult question, where the recipient of the plaintiff's information claimed to have subsequently and independently developed the same or similar information, although this particular defendant offered no supporting evidence to establish that defense. ${ }^{107}$ The appellate court reversed a judgment in the plaintiff's favor and

97. See Barsha v. Metro-Goldwyn-Mayer, 32 Cal. App. 2d 556, 565 (1939) (finding that trial court's error in confusing jury instructions was harmless and noting that "in numerous other instructions it was made clear to the jury that if [defendants] had independently conceived and prepared a composition which was not taken or copied from plaintiffs' work they would not be liable to plaintiffs for damages").

98. See Teich v. General Mills, Inc., 170 Cal. App. 2d 791, 795, 799-800, 803-05 (1959).

99. Id. at 795-96.

100. Id. at 794, 798

101. Id. at $801-02$.

102. Id. at 803 . The court did not make clear whether independent development was an affirmative defense or merely evidence negating an inference of use in favor of the plaintiff.

103. Hollywood Screentest of America, Inc. v. NBC Universal, Inc., 151 Cal. App. 4th 631, 647-48 (2007).

104. Id. at $633-36,639-40$.

105. Id. at $636-38$.

106. Id. at 646-48.

107. Donahue v. Ziv Television Programs, Inc., 245 Cal. App. 2d 593 (1966). 
remanded for a new trial as to the defendant studio, which asserted an independent development defense. ${ }^{108}$ The plaintiff sued the television studio and its employee over a format for an underwater adventure show. ${ }^{109}$ The studio argued for independent conception by its employee, but the plaintiff alleged that it disclosed the idea to both the defendant's executives and to the employee. The trial court reversed a judgment in the plaintiff's favor on post-trial motions, but the appellate court noted that the independent development defense was "not nearly as compelling" as that in Teich, because it rested on "uncorroborated" testimony by the accused employee, as opposed to the third-party evidence offered in Teich. ${ }^{110}$

A 1982 case demonstrates the concept of pre-existing knowledge by a defendant's employees who had no contact with the plaintiff's submission. Mann v. Columbia Pictures, Inc. featured a convoluted fact pattern that ultimately led the trial court to grant judgment in favor of the defendants despite a jury verdict in favor of the plaintiffs on their Desny claim. ${ }^{111}$ Through a third party, the plaintiff had submitted an outline for a film set at a beauty salon. The third-party recipient, whose salary was paid by the defendant but who worked for a different company, was not involved in, and had no contact with, the personnel at the defendant studio who created the accused film. ${ }^{112}$ Nonetheless, he and another person who saw the outline both ended up working for the defendant before the accused film was released. ${ }^{113}$ The two employees who created the accused film script testified they had never seen the plaintiff's film outline, showed that the creation of their own script had started several years before the plaintiff's submission, and offered evidence that the defendant studio had never even received the film outline. ${ }^{114}$ On this record, the appellate court affirmed, noting that independent creation was a "complete defense against the contractual obligation alleged herein." 15

In a 2013 case, Morawski v. Lightstorm Entertainment, the plaintiff alleged that, in 1991, he submitted ideas for a film to a director, and that the director subsequently incorporated the ideas into a 2009 film. ${ }^{116}$ The plaintiff alleged that the director only began working on the accused film in 1995, years after receiving plaintiff's ideas. ${ }^{117}$ In response, the director submitted a forty-five-page affidavit showing how the ideas

\footnotetext{
108. Id. at 614 .

109. Id. at 597 .

110. Id. at 599 .

111. Mann v. Columbia Pictures, Inc., 128 Cal. App. 3d 628, 634-35 (1982) (affirming judgment for defendants).

112. Id. at $636-37$.

113. Id. at 639.

114. Id. at $642-45$.

115. Id. at 648,650 (affirming because there was no showing of access, and any contrary inference reached by the jury "was rebutted by clear, positive and uncontradicted evidence").

116. See Morawski v. Lightstorm Ent., Inc., NO. CV 11-10294 MMM (JCGx), 2013 U.S. Dist. LEXIS 189155, at*1-11 (C.D. Cal. Jan. 31, 2013) (granting summary judgment to defendant on Desny and other claims).

117. Id.
} 
had come to him throughout his career and were drawn from his prior work and other "well-known stories," leading to summary judgment for the defendants. ${ }^{118}$

The high-profile case Spinner $v$. ABC, also decided in 2013, involved subsequent independent development by the defendant's employees who had no access to the plaintiff's idea submission. ${ }^{119}$ In that case, the plaintiff had submitted a script to the studio in 1977 and followed up in 1991. He therefore alleged that a television show's producers must have had access to that submission when they produced a similar show in 2003. ${ }^{120}$ The reviewing court described the plaintiff's Desny claim as "a bare possibility of theoretical access premised on mere speculation." 121 Based on the defendants' extensive evidence of their creative process and testimony that they had never heard of the plaintiff or his ideas, and following Teich, Hollywood Screentest, and Mann, the court affirmed summary judgment for the defendant. ${ }^{122}$

In totality, these cases offer courts facing trade secret disputes a roadmap to improve adjudication of the independent derivation defense. Each of these idea submission decisions could be cited and applied as authority in a trade secret case, without necessitating any broader merger of California's trade secret and idea submission laws. Indeed, Teich, Hollywood Screentest, Ziv, Mann, Morawski, and Spinner reflect each of the six possible categories of independent derivation described above. ${ }^{123}$ Their considerations of the temporal aspect of the defense, and the identity of the person or entity alleged to have created the independent idea, point to a workable structure for analyzing this defense in trade secret cases as well.

118. Id. at *14, *17-22 (citing Teich to support its contention that "[e]vidence that defendants created [their film], however, can rebut an inference of use as a matter of law"). For a similar fact pattern in an unpublished California ruling, see Kightlinger v. White, No. B210802, 2009 Cal. App. Unpub. LEXIS 9345, at *26-31 (Nov. 23, 2009) (unpublished) (affirming summary judgment in favor of defendant where plaintiff alleged Desny claim over screenplay; as alternative to main holding, affirming that defendant successfully used events from his personal life and evidence of the screenplay's compositional history to prove his screenplay was an independent creation). This ruling is notable because the accused person directly received the plaintiff's submission, and the court expressly held that it was still possible for such a recipient to prevail on independent development. Cf. Sullivan v. Pure Flix Ent. LLC, No. B280305, 2018 Cal. App. Unpub. LEXIS 7713, at*50-56 (Nov. 15, 2018) (unpublished) (denying motion for summary judgment on independent development defense and concluding that it was a matter for the jury to decide whether defendants" "significant evidence of independent creation" overrode evidence that they took their idea from the plaintiffs ").

119. Spinner v. Am. Broad. Cos., Inc., 215 Cal. App. 4th 172 (2013).

120. Id. at 175-83, 185-94 (2013).

121. Id. at 187.

122. Id. at 185-94. For a similar ruling in an unpublished case, see Scottish Am. Media, LLC v. NBC Universal, Inc., No. B205344, 2009 Cal. App. Unpub. LEXIS 3282, at*6-16, *26-27 (Apr. 28, 2009) (unpublished) (affirming trial court's grant of summary judgment to defendants on plaintiff's Desny claim and claims for breach of confidence and other torts, where defendant independently developed its ideas for a television show that was similar to a well-known European television contest).

123. Whether the defense was successful or unsuccessful, Ziv and Morawski speak to the accused individual claiming independent development before or after receipt of the plaintiff's information, Teich and Hollywood Screentest speak to independent development by third parties before and after the plaintiff's idea submission, and Mann and Spinner speak to independent development by other employees before and after the plaintiff's idea submission. 


\section{Bringing the Idea Submission Independent Development Methodology into Trade Secret Law}

Borrowing from these idea submission cases, and thereby subdividing the concept of independent derivation into discrete categories for judicial analysis, would be an important advance in California trade secret case law because it would better enable courts to determine the weight and credibility of the defendant's evidence. Indeed, we can organize the defense into six categories: three where the information at issue existed before the plaintiff's alleged disclosure to the defendant or its agent (again, "pre-existing knowledge"), and three where the defendant obtained or developed the information at a time after the plaintiff disclosed the information to the defendant or its agent. We can also use this schema to determine the relevance and strength of the evidence the defendant might need to submit in each category.

First, when asserting pre-existing knowledge, a defendant might demonstrate independent derivation through a showing that the accused person already possessed the same or similar information, and held it as a trade secret, before the plaintiff disclosed the information to the accused party. Or, as variations on such pre-existing knowledge, a corporate defendant might show that other employees within the company had already developed the defendant's product or technology before the defendant received the plaintiff's information, whether through hiring their former employee or otherwise, ${ }^{124}$ or the defendant might show that it had already obtained such information from a third party before hiring the plaintiff's former employee or otherwise receiving their trade secret.

Second, when asserting subsequent independent derivation, a defendant might establish that, even though it had obtained secret information belonging to the plaintiff, it had nonetheless developed the same or similar information through independent methods at a later point in time. Of the six categories of independent derivation in this schema, this is clearly the most difficult one to establish, and thus might require a stronger evidentiary showing - because the same "contaminated" individual is claiming that he or she independently developed the same or similar information in a lawful manner.

And yet, a 1959 case demonstrates one way this type of independent derivation might be established in a trade secret context. In Lloyd Pest Control Company v. Lopez, the plaintiff claimed that it owned a secret pest control customer list and alleged that the defendant, a former employee, had used that information to take customers away from the plaintiff. ${ }^{125}$ However, the former employee was able to show that he had sent 2,000 announcement cards for his new business to residents of the same city, having obtained their addresses from the phone book, and then "canvassed certain neighborhoods in order to gain business."126 Perhaps impressed

124. For example, in Be In, Inc. v. Google, Inc., No. 12 CV 03373 LHK, 2013 U.S. Dist. LEXIS 147047 (N.D. Cal. Oct. 9, 2013), Google argued that U.S.-based employees had internally and independently developed the concepts and user interfaces for a video conference platform years before its UK-based employee met with the plaintiff. The author represented Google in that litigation.

125. Lloyd Pest Control Co. v. Lopez, 173 Cal. App. 2d 606, 608-09 (1959).

126. Id. at 609,612 . 
by the defendant's independent efforts in blanketing the area, as if he were newlyarrived and had no tie to the plaintiff, the court affirmed the verdict in his favor, albeit without explicitly describing the case as one of independent derivation. ${ }^{127}$

Two less controversial forms of subsequent independent derivation could arise where a corporate defendant points to a source other than the plaintiff. First, the defendant might demonstrate that, although it hired an employee who had learned a trade secret while working for the plaintiff, its other employees independently developed the same or similar information at a later point, without knowledge of the plaintiff's secret. Second, the defendant might show that a third party (such as a licensor) provided the same or similar information after it received the plaintiff's trade secret. These categories seemingly would require a lower threshold for the defendant to meet its intermediate burden of producing evidence, since they do not rely on the actions of the accused individual.

Examples of these concepts in trade secret cases are rare in California, and they have not been articulated with the level of detail seen in the idea submission cases. In one 2007 trade secret case, a court granted summary judgment to the defendants on a customer list-based trade secret claim. ${ }^{128}$ The defendant showed that it had obtained its own customer list from third parties, and that one customer contact received from the plaintiff's former employee actually originated before the former employee worked for the plaintiff. ${ }^{129}$ Although the discussion was cursory, this case illustrates two different types of independent derivation: subsequent acquisition from a third-party source, and pre-existing knowledge.

Overall, subdividing the concept of independent derivation into these distinct categories would provide greater clarity and rigor in testing the defense, as well as allowing parties to provide a more organized presentation and allowing courts more clarity in weighing the evidence. It would also highlight situations where witness credibility is more important, or where timestamped records could easily establish the defense with no testimony at all. In addition, this subdivision would fill a gap in the commentary, where scholarly work in this area and detailed analysis in the treatises are almost nonexistent. ${ }^{130}$

Inspired by the six idea submission cases discussed above (Teich, Hollywood Screentest, Ziv, Mann, Morawski, and Spinner), the following schema shows how the defense of independent derivation could be organized in trade secret cases:

127. Id. at 612 . Using then-current terminology, the court found that there had been no "unfair competition."

128. Rita Med. Sys. v. Resect Med., Inc., No. C 05-03291 WHA, 2007 U.S. Dist. LEXIS 7810, at *22-23 (N.D. Cal. Jan. 17, 2007).

129. Id.

130. See, e.g., Roger Milgrim, An Independent Derivation Defense To Patent Infringement: The Academy Talking To Itself: Should Anyone Listen?, 90 J. PAT. \& TRADEMARK OFF. SOC'Y 295, 301-02 (2008) (providing overview of how independent derivation properly fits within the structure of trade secret law, in order to demonstrate why such a defense would be improper in the patent context and thus does not contain detailed analysis of trade secret case law). 
Independent Derivation: Temporal Axis and Sources of Independent Information

\begin{tabular}{|c|c|c|c|}
\hline & $\begin{array}{l}\text { Individual: } \\
\text { Self- } \\
\text { Development }\end{array}$ & $\begin{array}{l}\text { New Employer: } \\
\text { Self- } \\
\text { Development }\end{array}$ & $\begin{array}{l}\text { New Employer: } \\
\text { Other Source }\end{array}$ \\
\hline $\begin{array}{l}\text { Independent } \\
\text { derivation } \\
\text { before } \\
\text { Plaintiff's } \\
\text { disclosure of } \\
\text { trade secret to } \\
\text { Defendant } \\
\text { ("pre-existing } \\
\text { knowledge") }\end{array}$ & $\begin{array}{l}\text { Accused person } \\
\text { already } \\
\text { developed same } \\
\text { or similar } \\
\text { information } \\
\text { before first } \\
\text { contact with } \\
\text { Plaintiff }\end{array}$ & $\begin{array}{l}\text { Accused } \\
\text { business had } \\
\text { already } \\
\text { internally } \\
\text { developed same } \\
\text { or similar } \\
\text { information } \\
\text { before hiring } \\
\text { employee who } \\
\text { learned the trade } \\
\text { secret from } \\
\text { Plaintiff }\end{array}$ & $\begin{array}{l}\text { Accused business } \\
\text { had already } \\
\text { received same or } \\
\text { similar } \\
\text { information from } \\
\text { a third party } \\
\text { before hiring } \\
\text { employee who } \\
\text { learned the trade } \\
\text { secret from } \\
\text { Plaintiff }\end{array}$ \\
\hline $\begin{array}{l}\text { Independent } \\
\text { derivation } \\
\text { after Plaintiff's } \\
\text { disclosure of } \\
\text { trade secret to } \\
\text { Defendant }\end{array}$ & $\begin{array}{l}\text { Accused person } \\
\text { claims that he or } \\
\text { she developed } \\
\text { the same or } \\
\text { similar } \\
\text { information after } \\
\text { learning that } \\
\text { information from } \\
\text { Plaintiff }\end{array}$ & $\begin{array}{l}\text { Accused } \\
\text { business has } \\
\text { other employees } \\
\text { who } \\
\text { independently } \\
\text { develop the same } \\
\text { or similar } \\
\text { information after } \\
\text { hiring employee } \\
\text { who learned the } \\
\text { trade secret from } \\
\text { Plaintiff }\end{array}$ & $\begin{array}{l}\text { Accused business } \\
\text { obtains same or } \\
\text { similar } \\
\text { information from } \\
\text { a third party or a } \\
\text { different } \\
\text { employee after } \\
\text { hiring employee } \\
\text { who learned the } \\
\text { trade secret from } \\
\text { Plaintiff }\end{array}$ \\
\hline
\end{tabular}

\section{B. Preemption of Common law Intellectual Property Tort Claims: Does the California Uniform Trade Secret Act Preempt Any Idea SUBMISSION THEORIES?}

Although independent derivation is an important defense in trade secret law, and although great benefit could come from looking to similar idea submission cases to articulate and provide heft to that neglected issue, this partial merger need not lead to a corollary shift in the formal structure of either doctrine. There is, however, another area where California trade secret and idea submission law overlap; a merger here indeed would alter the formal structure of idea submission law, narrowing the subject matter a plaintiff could claim as protectable. That overlap is the California Uniform Trade Secrets Act preemption doctrine, which prohibits tort claims brought 
under causes of action that seek to penalize the use or disclosure of confidential business information.

In both trade secret and idea submission cases, California plaintiffs often attempt to allege multiple common law tort claims - under labels such as conversion, unfair competition, common law misappropriation, breach of confidence, and the likealongside their statutory claims (the CUTSA and the federal Copyright Act, respectively) and breach of contract claims. The goal of asserting these additional tort claims is always to enlarge the scope of what the plaintiff wants to deem protectable. That is, litigants seek to create their own self-declared and self-defined categories of protectable information, rather than staying within the limitations and boundaries provided by formal, legislatively recognized categories such as patent law, copyright law, and trade secret law, or by the terms of agreed-upon contracts.

In response, defendants often argue that such common law tort claims are preempted by formal, statutory intellectual property regimes, and therefore should be dismissed outright because any concession to the plaintiff would undermine the limited boundaries for protection that legislative bodies have defined, and would thereby subvert the established IP systems. These preemption arguments take three forms, in reference to three intellectual property statutes, but they are largely aimed at the same problem. ${ }^{131}$ A great many disputes have been waged over federal patent preemption of tort claims where a plaintiff seeks to protect unpatented, publiclyavailable inventions, federal copyright preemption of tort claims where a plaintiff seeks to protect non-copyrightable works, and state trade secret preemption of tort claims where a plaintiff seeks to protect allegedly nonpublic business information or other information not protected by the trade secrets statute. ${ }^{132}$

It is easy to describe how litigants raise preemption to block tort claims, as this is merely a matter of observation. It is less common, however, to analyze what the contours of IP preemption are. Even courts that have ruled on preemption disputes rarely address the policy goals achieved by suppressing state law tort claims that seek an end run around the boundaries and requirements of statutory IP regimes. What,

131. To be clear, the federal trade secret statute, the Defend Trade Secrets Act, does not displace state law. See 18 U.S.C. $\S 1838$. Preemption of state law tort claims that clash with the requirements of trade secret law is accomplished through the California Uniform Trade Secrets Act, not federal law.

132. For copyright preemption, see cases cited infra notes 137-145. Trade secret preemption case law is discussed in detail below. For a California example of patent preemption of state law tort claims premised on unpatented, publicly available ideas of the type encompassed by the patent laws, see Sammons \& Sons v. Ladd-Fab, Inc., 138 Cal. App. 3d 306, 312-13 (1982) (relying on U.S. Supreme Court and other decisions to hold that an unfair competition claim based on defendant's copying of nonsecret product designs was preempted). For similar patent preemption decisions elsewhere, see Compco Corp. v. Day-Brite Lighting, Inc., 376 U.S. 234, 237-39 (1964) (information not covered by a patent could not form basis for state law unfair competition claim); Sears, Roebuck \& Co. v. Stiffel Co., 376 U.S. 225, 228-32 (1964) (same); Confold Pac., Inc. v. Polaris Indus., Inc., 433 F.3d 952, 959-60 (7th Cir. 2006) (unjust enrichment claim based on non-secret technical information preempted: "In general, if information is not a trade secret and is not protected by patent, copyright, or some other body of law that creates a broader intellectual property right than trade secrecy does, anyone is free to use the information without liability."); Ultra-Precision Mfg., Ltd. v. Ford Motor Co., 411 F.3d 1369, 1378-80 (Fed. Cir. 2005) (same). 
then, is the point of trade secret preemption, copyright preemption, and patent preemption?

The answer is that doctrines like CUTSA preemption prevent IP statutes from being permanently undermined by litigants who would otherwise use tort claims, with their blurry boundaries and uncertain standards, to acquire IP rights in ideas, writings, and information that fail to qualify for statutory protection. Such tort claims lower the protectability bar. While IP statutes attempt to balance competing factors to serve the public interest, a litigant's tort claim seeks maximal protection and shortterm self-interest, with little or no consideration of externalities.

Thus, someone who brings a tort claim to protect some ostensible IP right is always - always - attempting to lower the bar on what is protectable (and thus, to withdraw information from the public domain), which is necessarily an attempt to claim rights in information not otherwise protectable under the IP statutes. It is a deliberate strategy, and what we might call a "heads I win, tails I win" strategy, where the plaintiff seeks to achieve IP rights even if its statutory claim is destined to fail. More direct awareness by courts of the motivations underlying plaintiffs' strategy in these cases would be illuminating. Unfortunately, this blunt assessment is rarely seen in court rulings and academic commentary; it is certainly heard least in the hallways of law firms, which want to maximize their opportunities for wins on behalf of plaintiff clients.

In California, CUTSA preemption is a broad and powerful doctrine, one endorsed by the courts of appeal and applied routinely over the past decade in countless trial court rulings. This Article proposes that CUTSA preemption also would apply to tort claims brought in the idea submission context, where those claims seek to protect purportedly confidential information. To readers well-versed in idea submission disputes, this may seem a surprising idea. After all, courts spent years wrestling with the question whether the Copyright Act preempts any types of idea submission claims, until the Ninth Circuit ruled definitively on that question in 2004, and again in 2010. But the argument here is that the CUTSA has a similar role to play: It can and should preempt any and all California tort causes of action that are premised on the supposed confidentiality of the information or ideas at issue. Even so, the CUTSA would not preempt the core Desny cause of action for breach of implied-infact contract. To explore this proposal, we first review how idea submission law struggled with copyright preemption, and then address the proposal for analogous CUTSA preemption.

\section{California Idea Submission Claims and Partial Copyright Preemption}

Perhaps because California's idea submission claims developed from a common law copyright history, it is unsurprising that copyright preemption under the 1976 Copyright Act became a major battleground, especially when plaintiffs brought tort claims such as breach of confidence over film and television scripts. The underlying dispute took up an enormous amount of judicial attention, especially in the 1990s 
and 2000s. It also attracted much commentary. ${ }^{133}$ And although defendants have attempted to block idea submission claims through other theories such as California's anti-SLAPP statute ${ }^{134}$ (on the theory that the accused work constituted protected speech) ${ }^{135}$ and even the Labor Management Relations Act, ${ }^{136}$ copyright preemption easily generated the most rulings.

As copyright preemption disputes began gaining traction, many defendants successfully argued that the Copyright Act preempted California tort claims such as unfair competition or unjust enrichment. Some courts ruled that only federal copyright law could govern the distribution and reproduction of the allegedly

133. See Catherine Niebergall, Note, Product of the Mind: Idea Submission Cases and Copyright Preemption Post-Grosso, 17 SMU SCI. \& TECH. L. ReV. 31, 56-58 (2014) (reviewing then-recent copyright preemption cases in the Ninth and Second Circuits); Julie A. Byren, Note, When the MillionDollar Pitch Doesn't Pay a Dime: Why Idea Submission Claims Should Survive Copyright Preemption, 28 BERKELEY TECH. L.J. 1037, 1065-68 (2013) (thoughtful review of then-recent Ninth and Second Circuit cases on copyright preemption in the idea submission context, reviewing policy considerations for not preempting state law contract-based claims, and noting that a contract theory under Desny reflects "the power imbalance between producers and screenwriters" as justifying "additional measures of protection for submission materials" and commenting on how studios have "a great deal of leverage" due to the "growing disparity between the supply of writing talent and the demand for it"); Aileen Brophy, Whose Idea Is It Anyway? Protecting Idea Purveyors and Media Producers After Grosso v. Miramax, 23 CARDOZO ARTS \& ENT. L.J. 507, 527 (2005) (expressing a concern that studios would react to Grosso by requiring contracts containing releases with idea submitters, "leaving unknown writers with even less bargaining power than they had before"); Celine Michaud \& Gregory Tulquois, Idea Men Should Be Able To Enforce Their Contractual Rights: Considerations Rejecting Preemption of Idea-Submission Contract Claims, 6 VAND. J. ENT. L. \& PRAC. 75, 88 (2003) (analyzing idea submission cases in New York and California to argue that the Copyright Act does not expressly or impliedly preempt state law contractbased claims); Glen L. Kulik, Copyright Preemption: Is This the End of Desny v. Wilder?, 21 LoY. ENT. L. REV. 1, 9 (2000) (survey of then-recent case law on copyright preemption question and noting the "profound disagreement" at that time).

134. California's statute barring Strategic Lawsuits Against Public Participation was intended to prevent corporations from using lawsuits to squelch protest activity, but it has become something of an octopus in the courts, as litigants seek to use the statute to block lawsuits over a wide variety of speechrelated activities. See CAL. CIV. Proc. CODE $\S 425.16$. To strike a cause of action, the movant must show that the act giving rise to the claim was done in furtherance of the right to petition or free speech, or was done in connection with a public issue and, if that threshold showing is satisfied, the non-moving party must show a probability of prevailing on the challenged claim. See generally Navellier v. Sletten, 29 Cal. 4th $82,88-89$ (2002).

135. See Jordan-Benel v. Universal City Studios, Inc., 859 F.3d 1184, 1191-93 (9th Cir. 2017) (in a lawsuit over a "screenplay idea," the defendant moved to strike plaintiff's state law Desny claim under California's SLAPP statute, and the court affirmed the trial court in denying the anti-SLAPP motion because a claim alleging a "failure to pay for the use of a screenplay idea" is not a claim aimed at protected speech activities). See also Wilder v. CBS Corp., 2:12-cv-8961-SVW-RZ, 2013 U.S. Dist. LEXIS 190059, at *27-28 (C.D. Cal. Feb. 13, 2013) (granting certain defendants' motion to strike plaintiff's claims for tortious interference, civil conspiracy, and section 17200 unfair competition on anti-SLAPP grounds, finding among other things that plaintiff could not demonstrate a probability of prevailing because the court had found them to be copyright-preempted).

136. See Spinner v. ABC Co., CV 09-07247 RGK (RCx), 2009 U.S. Dist. LEXIS 138253, at *7-8 (C.D. Cal. Dec. 21, 2009) (when plaintiff claimed right to payment for contribution to a television program and filed a Desny claim, defendant removed to federal court in an attempt to argue that the LMRA preempted the claim; defendant argued that a Writer's Guild Collective Bargaining Agreement had to be interpreted, presenting a federal question; court rejected the argument because a prior arbitration in the same dispute already had interpreted the agreement in plaintiff's favor, and thus there was no aspect of the agreement that a federal court needed to interpret). 
protectable expressive work, and that the asserted tort claims offered nothing qualitatively different from federal copyright law. ${ }^{137}$

Desny claims for breach of an implied-in-fact contract, however, proved nettlesome. Some courts found that the Copyright Act preempted even contractbased idea submission claims. ${ }^{138}$ One, a 2000 case in the Central District of California, reasoned that the Desny claim "does not regulate anything other than defendant's use of plaintiff's works." 139 But other courts found that the Copyright Act did not preempt Desny claims, reasoning variously that the contract claim encompassed distinct subject matter or that it included the differentiating element of misrepresentation. ${ }^{140}$

With the district courts divided, the Ninth Circuit stepped in. ${ }^{141}$ Starting in 2004, with Grosso v. Miramax, the court first reviewed the well-established, two-part test

137. See Berkla v. Corel Corp., 66 F. Supp. 2d 1129, 1146-50 (E.D. Cal. 1999) (in copyright dispute over database images of plants, court found that claim for breach of express nondisclosure agreement was partly copyright-preempted to the extent it sought to litigate the release of images, but not preempted as to contractual duties to avoid "over-dissemination and use" of the images," and found the same as to claims for breach of confidence and unfair competition under section 17200); Trenton v. Infinity Broad. Corp., 865 F. Supp. 1416, 1427-29 (C.D. Cal. 1994) (in a somewhat unusual dispute over a radio program format where the defendant was found to own recorded broadcasts under the Work for Hire doctrine, plaintiff's long list of state law tort claims was found to be copyright-preempted on summary judgment, but the express and implied contract claims were remanded to state court for further proceedings because they were "qualitatively different from the copyright infringement claim"); Anderson v. Stallone, No. 870592 WDK (Gx), 1989 U.S. Dist. LEXIS 11109, at*10-15 (C.D. Cal. Apr. 25, 1989) (screenwriter sued defendants over treatment for boxing-related movie; as to two of several claims asserted, unfair competition and unjust enrichment under state law, the court granted defendants' motion for summary judgment because both were copyright-preempted: "Both actions are grounded on the defendants' alleged use of a written script .... There is no 'extra element' such as fraud or palming off to save the unfair competition and unjust enrichment claims from preemption.").

138. See Metrano v. Fox Broad. Co., Inc., No. 87-0592 WDK (Gx), 2000 U.S. Dist. LEXIS 7662, at *18-20 (C.D. Cal. Apr. 24, 2000) (plaintiff sued over concept for television series and alleged causes of action for breach of implied contract and breach of confidence; defendant removed and moved to dismiss; and court found that the implied contract claim was copyright-preempted because it "does not regulate anything other than defendant's use of plaintiff's works," but found that breach of confidence was not copyright-preempted because it featured the "extra element" of an agreement to maintain confidentiality); Selby v. New Line Cinema Corp., 96 F. Supp. 2d 1053, 1062 (C.D. Cal. 2000) (where plaintiff sued over screenplay and included implied contract claim, court dismissed that claim, finding that it alleged no additional rights other than those in a copyright infringement claim).

139. See Metrano, 2000 U.S. Dist. LEXIS 7662 at $* 18-20$.

140. See Groubert v. Spyglass Ent. Group, LP, CV 02-01803-SVW (JTLx), 2002 U.S. Dist. LEXIS 17769 , at *8-16 (C.D. Cal. 2002) (where plaintiff brought state and federal claims over pitch of story idea to studio, court found on motion to dismiss that claims for breach of implied contract as well as breach of confidence were not copyright-preempted, ruled that the implied contract claim could cover ideas that would not be within the scope of copyright law, and found that the breach of confidence claim had the "extra element" of an alleged confidential relationship); Miller v. Miramax Film Corp., No. CV 99-08526 DDP (AJWx), 1999 U.S. Dist. LEXIS 23422, at*11 (C.D. Cal. 1999) (where plaintiff sued over alleged infringement of screenplay and also asserted state law claims, court found on motion to dismiss that, among other things, Desny implied contract claim was not copyright-preempted, also finding that the fraud claim was not copyright-preempted because it had the "extra element" of misrepresentation and it would be "premature" to dismiss a tortious interference claim on preemption grounds).

141. Grosso v. Miramax Film Corp., 383 F.3d 965, at 968 (9th Cir. 2004), amended 400 F.3d 658 (9th Cir. 2005) (where plaintiff alleged that defendants misused his idea for a screenplay and filed causes 
for copyright preemption of state law claims: (1) whether the work at issue comes within the subject matter of the Copyright Act; and (2) whether the state law rights asserted in the plaintiff's challenged cause(s) of action are equivalent to any of the exclusive rights that are within the general scope of copyright law. To survive copyright preemption, the state law claim must protect a right that is qualitatively different from the rights protected by copyright law, meaning that the state law claim must feature an "extra element" rendering it qualitatively different. ${ }^{142}$ In Grosso, the court found that the plaintiff's Desny claim was not copyright-preempted because an implied-in-fact contract involves a "bilateral expectation of compensation," thus providing the "extra element" to distinguish the claim from copyright infringement. ${ }^{143}$

Apart from Desny claims, courts generally found that the Copyright Act does not preempt common law tort claims for breach of confidence. Some ruled that because the tort contemplates a disclosure in confidence, that element of confidentiality provided the "extra element" to avoid copyright preemption. ${ }^{144}$ Notably, for purposes of the discussion to follow, this confidentiality rationale is the same reason that the Copyright Act does not preempt state law trade secret claims. ${ }^{145}$ One court did rule that the Copyright Act preempted breach of confidence claims if the claim was premised on publicly disclosed information, but that was a unique fact pattern that did not disturb the consensus around this cause of action. ${ }^{146}$

of action for copyright infringement and for a state-law Desny claim, court reversed a trial court finding on a motion to dismiss that the claim was copyright-preempted, finding that the "implied promise to pay required by Desny" is an extra element sufficient to overcome preemption); see also Benay v. Warner Bros. Ent., Inc., 607 F.3d 620, 629 (9th Cir. 2010) (noting rule from Grosso that Desny claims are not copyright-preempted). An earlier, non-precedential Ninth Circuit case regarding copyright preemption was inconclusive. See Star Patrol Enter., Inc. v. Saban Ent., Inc., No. 95-56534, 1997 U.S. App. LEXIS 29994, at *10-11 (9th Cir. 1997) (unpublished) (where plaintiff alleged misuse of ideas for a television series and related products and raised state-law causes of action for breach of implied contract and breach of confidence, court reversed finding that amendment of breach of confidence claim would be futile due to copyright preemption, as "[d] iscovery is required before a meaningful examination of preemption issues can occur" in a "fact-driven" situation). Even earlier, the court hinted that a Desny claim was not copyright-preempted without specifically analyzing the question. See Landsberg v. Scrabble Crossword Game Players, Inc. (Landsberg II), 802 F.2d 1193, 1196 (9th Cir. 1986) (affirming judgment in favor of plaintiff on Desny claim where he submitted a manuscript for a board game strategy to the gamemaker, who used it without compensation: "[T] property interest, however, but upon the implied promise to pay the reasonable value of the material disclosed.").

142. See Grosso, 383 F.3d at 968.

143. Id.

144. See Groubert, 2002 U.S. Dist. LEXIS 17769 at *8-16; Metrano, 2000 U.S. Dist. LEXIS 7662 at $* 18-20$.

145. The Copyright Act does not preempt state law trade secret claims because the alleged confidentiality of the information provides the "extra element" sufficient to render such claims qualitatively different than copyright claims for purposes of copyright preemption. See, e.g., AtPac, Inc. v. Aptitude Sols., Inc., 787 F. Supp. 2d 1108, 1114-16 (E.D. Cal. 2011) (typical ruling finding that a trade secret cause of action is not copyright-preempted).

146. See Berkla, 66 F. Supp. 2d at 1150-51 (finding that the Copyright Act did not preempt a breach of confidence claim to the extent it was premised on an agreement to use confidential images only for purposes of evaluation, but preempting the claim to the extent it was based on images that had been publicly released). 
The Ninth Circuit endorsed this logic in Montz v. Pilgrim Films \& Television, Inc., finding that a California breach of confidence claim was not preempted by the Copyright Act because the cause of action relies on the "extra element" of a confidential relationship between the parties, rendering it qualitatively different from the rights that are adjudicated under a federal copyright infringement claim. ${ }^{147}$

Following Grosso and Montz, the district courts facing idea submission lawsuits have ruled that the Copyright Act does not preempt plaintiffs' Desny or breach of confidence claims, but have found other types of tort claims preempted. ${ }^{148}$ The survival of these claims leads us to ask whether other forms of intellectual property preemption might displace them, even where the Copyright Act does not. The answer is that California's version of the Uniform Trade Secret Act preempts breach of confidence claims beyond any doubt, but almost certainly does not preempt a Desny claim for breach of implied-in-fact contract.

\section{Trade Secret Preemption of California Idea Submission Claims}

The doctrine of California Uniform Trade Secrets Act preemption should eliminate all tort claims - in any context, including idea submission cases — where a plaintiff alleges the defendant misused allegedly nonpublic (confidential) business

147. Montz v. Pilgrim Films \& Television, Inc., 649 F.3d 975, 981 (9th Cir. 2010) (where plaintiff alleged misuse of novel ideas for television program and sued on state law claims for breach of implied contract and breach of confidence, court reversed trial court finding that both claims were copyrightpreempted; following Grosso as to the Desny claim and, as to the breach of confidence claim, holding that it "also survives copyright preemption. The claim protects the duty of trust or confidential relationship between the parties, an extra element that makes it qualitatively different from a copyright claim.").

148. See Alexander v. MGM Studios, Inc., No. CV 17-3123-RSWL-KSx, 2017 U.S. Dist. LEXIS 214497, at *26 n.8 (C.D. Cal. Aug. 14, 2017) (finding unjust enrichment claim copyright-preempted); Counts v. Meriwether, No. 2:14-cv-00396-SVW-CW, 2015 U.S. Dist. LEXIS 165723, at*13-16 (C.D. Cal. June 12, 2015) (on plaintiff's motion to dismiss in case over television script, the court dismissed conversion claim as copyright-preempted, noting that scope of copyright preemption is broader than that which is strictly protected by copyright law); Dillon v. NBCUniversal Media, LLC, No. CV 12-09728 SJO (AJWx), 2013 U.S. Dist. LEXIS 100733, at *24-32 (C.D. Cal. June 18, 2013) (on motion to dismiss, plaintiff's Desny claim and its section 17200 unfair competition claim which was predicated on the Desny claim were not copyright-preempted); Wilder v. CBS Corp., No. 2:12-cv-8961-SVW-RZ, 2013 U.S. Dist. LEXIS 190059, at *15-26 (C.D. Cal. Feb. 13, 2013) (on motion to dismiss in case over talk show "treatment," court found state law tort claims for tortious interference, civil conspiracy, and unfair competition against some defendants under section 17200 copyright-preempted); see also Hog Dogs \& Lace, LLC v. A\&E TV Networks, LLC, Civil Action No. 1:12-cv-583, 2013 U.S. Dist. LEXIS 93700, at *12-15 (E.D. Tex. May 21, 2013) (on motion to remand to state court in case over ideas for television show, court found little Fifth Circuit authority on "Desny-type claims" and looked to Grosso and Desny as authority to find that implied contract claim was not copyright-preempted, and also finding that that various tort claims were not preempted, but without analysis because "the claims, by the parties' own admissions, rise and fall with the implied breach of contract claim"); Identity Arts v. Best Buy Ent. Serv., Inc., Nos. C 05-4656 PJH, C 06-1631 PJH, 2007 U.S. Dist. LEXIS 32060, at *56-60 (N.D. Cal. Apr. 18, 2007) (on motion for judgment on the pleadings in case involving "marketing strategy" for presenting cell phone reminders in theaters alongside movie trailers, court found that state law claims for unjust enrichment and unfair competition under section 17200 were copyright-preempted because they were "expressly based upon the material covered by plaintiff's copyright claims," but found that implied contract claim under Desny was not copyright-preempted due to its "extra element of implied promise to pay for the ideas," following Grosso). 
information. ${ }^{149}$ Especially in the idea submission context, that would lead to the end of the breach of confidence tort, as well as other tort claims asserted in that context such as common law misappropriation, unfair competition, and the like. Where copyright preemption does not apply to California tort claims because the tort claim is predicated on supposedly confidential information, the CUTSA steps into that gap to preclude such causes of action.

Applying both copyright preemption and CUTSA trade secret preemption in the idea submission context would leave only contract-based claims, including the central Desny claim for implied-in-fact contract. This would be an optimal result, because it would preserve the special claim created by the California Supreme Court to protect less powerful parties against studios in a very specific context, while preventing litigants from raising claims over confidential business information in a manner that subverts the careful balancing of interests underlying the CUTSA's delineation of claims, defenses, and procedures.

\section{a. A History of Uniform Trade Secrets Act Preemption in California}

Although CUTSA preemption in California is now a relatively straightforward matter, it took almost twenty-five years after the statute became effective on January 1,1985 for the law to reach its current state. To be sure, the model version of the Uniform Trade Secrets Act contains an express preemption clause, and most states have adopted some form of it. ${ }^{150}$ But its awkward phrasing (including in the California version) has contributed to a fair amount of confusion among the states construing it, and may explain California's own delay in fully implementing it. ${ }^{151}$

149. I use the phrase "business information" to exclude personal and consumer information of the type regulated by the state and federal privacy laws.

150. See CAL. CIV. CODE $\S 3426.7$ (b) (West 2020) ("This title does not affect (1) contractual remedies, whether or not based upon misappropriation of a trade secret, (2) other civil remedies that are not based upon misappropriation of a trade secret, or (3) criminal remedies, whether or not based upon misappropriation of a trade secret."). Preemption disputes over tort claims turn on subsection (2), as the other subsections refer to breach of contract claims and to criminal prosecutions for trade secret misappropriation under California Penal Code section 499c. Notably, because California prohibits noncompetition agreements, the existence of a contract claim does not provide an employer with an end-run around the CUTSA where it can successfully protect information that is not a trade secret. Indeed, contract claims seeking to stop a departing employee from using non-secret information, such as customer identities, have been voided under Business and Professions Code section 16600. See, e.g., AMN Healthcare, Inc. v. Aya Healthcare Servs., Inc., 28 Cal. App. 5th 923, $943-44$ (2018) (voiding postemployment clause that prohibited solicitation of former employer's employees); Dowell v. Biosense Webster, Inc., 179 Cal. App. 4th 564, 578 (2009) (voiding clauses that restricted solicitation of customers beyond narrow misuse of trade secrets); Thompson v. Impaxx, Inc., 113 Cal. App. 4th 1425, 1429-32 (2003) (contract barring solicitation of customers void to the extent customer information did not constitute trade secrets); Edwards v. Arthur Andersen LLP, 44 Cal. 4th 937 (2008) (voiding postemployment clause which barred contact with customers for eighteen months).

151. Although a majority of states - in supreme court and published appellate court decisions- - have ruled in favor of UTSA preemption, a surprising and persistent minority has not. The latter rulings are notable for their failure to analyze the issue at any depth, and their misunderstandings of the statutory text. For examples of majority-position rulings, see generally Robbins v. Supermarket Equip. Sales, LLC, 722 S.E.2d 55, 58 (Ga. 2012) (approving prior Georgia case law to hold that allowing injunctive relief for 
From the start, it might have seemed that the UTSA would quickly block all other tort claims seeking to penalize others for misuse of asserted nonpublic information. When California enacted its version of the UTSA, and in line with the drafters' comments, the legislative history indicated that the "contribution" of the statute was to replace the confusing variety of tort claims that litigants had used to bring similar claims: the "substitution of unitary definitions of trade secret and trade secret misappropriation, and a single statute of limitations for the various property, quasicontractual, and violation of fiduciary relationship theories of noncontractual liability utilized at common law."152 Moreover, the California courts have given broad preemptive scope to comprehensive statutory enactments, ${ }^{153}$ and have continued to interpret other Uniform Acts to preempt overlapping tort claims. ${ }^{154}$

information that failed to qualify as a trade secret "undermined the exclusivity of the GTSA"); HDNet, LLC v. N. Am. Boxing Council, 972 N.E.2d 920, 924 (Ind. Ct. App. 2012) (following rulings from other states); CDC Restoration \& Constr., LC v. Tradesmen Contractors, LLC, 274 P.3d 317, 330 (Utah Ct. App. 2012) ("[W]e join the majority of courts that have addressed this issue and hold that the UTSA preempts claims based on unauthorized use of information, irrespective of whether that information meets the statutory definition of a trade secret."); Rogers Indus. Prod., Inc. v. HF Rubber Mach. Inc., 936 N.E.2d 122, 130 (Ohio Ct. App. 2010) (Ohio UTSA preempts claims "based solely on allegations of misappropriation of trade secrets or other confidential information"); BlueEarth Biofuels, LLC v. Hawaiian Elec. Co., Inc., 235 P.3d 310 (Haw. 2010) (describing the current state of UTSA preemption law nationwide, and siding with other state supreme courts in favoring the majority approach of endorsing preemption); Thola v. Henschell, 164 P.3d 524, 529-30 (Wash. Ct. App. 2007) (taking the majority position, but deciding against preemption on facts where tortious interference claim "does not involve the acquisition or disclosure of confidential information"); Mortg. Specialists, Inc. v. Davey, 904 A.2d 652, 665 (N.H. 2006) (affirming pre-trial order dismissing alternative claims, ruling that UTSA is intended as sole claim for trade secret misuse); RK Enter., LLC v. Pro-Comp Mgmt., Inc., 158 S.W.3d 685, 689-90 (Ark. 2004) (reversing trial court; finding broad preemption of alternative tort claim); Infinity Prods., Inc. v. Quandt, 810 N.E.2d 1028, 1034 (Ind. 2004); Savor, Inc. v. FMR Corp., 812 A.2d 894, 898 (Del. 2002) (affirming preemption of unfair competition and conspiracy claims at the pleading stage); Dicks v. Jensen, 768 A.2d 1279, 1285 (Vt. 2001) (holding that UTSA preemption applies to common law claims even if the information does not meet the statutory definition of a trade secret); Frantz v. Johnson, 999 P.2d 351, 357-58 (Ne. 2000) (reversing trial court and holding in favor of broad preemption of various alternative tort claims); Weins v. Sporleder, 605 N.W.2d 488, 492 (S.D. 2000) (reversing trial court and holding in favor of broad preemption, explaining that it would render the UTSA "meaningless" if a plaintiff"s trade secret claim is dismissed and "plaintiffs can simply pursue the same claim in the name of a tort"). For examples of the minority position, see generally Am. Biomed. Grp., Inc. v. Techtrol, Inc., 374 P.3d 820, 827-28 (Okla. 2016) (misreading statutory text and ignoring UTSA commentary for simplistic ruling that statute does not preempt purported torts over information said to be confidential but not secret, whatever that is supposed to encompass); Burbank Grease Servs., LLC v. Sokolowski, 717 N.W.2d 781 (Wisc. 2006) (ruling, over passionate dissent, against preemption of alternative tort claims despite preemption clause in Wisconsin UTSA).

152. See Letter from Assemblyman Elihu Harris to Governor George Deukmejian (Sep. 12, 1984) (on file with author); AsSEMB. B. 501, Dig. (Cal. 1983) (on file with author).

153. See Pac. Scene, Inc. v. Peñasquitos, Inc., 46 Cal. 3d 407, 411 (1988) ("[G]eneral and comprehensive legislation" which carefully describes the course of conduct affected and spells out limitations and exceptions, "indicates a legislative intent that the statute should totally supersede and replace the common law dealing with the subject matter." (citing I.E. Assoc. v. Safeco Title Ins. Co., 39 Cal. 3d 281, 285-86 (1985)).

154. See, e.g., Zengen, Inc. v. Comerica Bank, 41 Cal. 4th 239, 251-55 (2007) (broad California Uniform Commercial Code preemption); Bishop v. Hyundai Motor Am., 44 Cal. App. 4th 750, 757 (1996) (UCC preemption); Briseno v. City of Santa Ana, 6 Cal. App. 4th 1378, 1382 (1992) (Uniform Housing 
Nevertheless, no court applying California law appears to have seriously considered CUTSA preemption until a flurry of rulings began in the early $2000 \mathrm{~s}$, with one notable exception in 1997. ${ }^{155}$ After a federal district court interpreted the CUTSA preemption clause broadly in what would become a widely-cited ruling, ${ }^{156}$ most trial courts began to do the same, often at the pleading stage on a motion to dismiss (in federal district court) or a demurrer (in state trial court). ${ }^{157}$ One such case, in 2005, adopted a "common nucleus of fact" test to determine which tort claims the CUTSA preempts. ${ }^{158}$ All the same, a minority of trial courts ruled against CUTSA preemption, typically without fully considering (or even mentioning) the statutory text, the legislative history, California's general rules for statutory preemption of common law, similar rulings under other Uniform Acts, or the policy effects of taking such a position. ${ }^{159}$

Three major rulings between 2009 and 2012 created the present rules for CUTSA preemption in California. First, a California court of appeal finally reached the issue in 2009, in K.C. Multimedia, Inc. v. Bank of America Technology \& Operations, Inc., ruling in favor of broad CUTSA preemption of overlapping tort claims. ${ }^{160}$ The court adopted the "common nucleus of fact" test created by a federal court four years earlier and found several tort claims CUTSA-preempted as a matter of law. ${ }^{161}$

Code preemption); Gil v. Bank of Am., Nat'l Ass'n, 138 Cal. App. 4th 1371, 1376, 1380 (2006) (affirming UCC preemption of common law claims at demurrer stage); Joffe v. United Cal. Bank, 141 Cal. App. 3d 541, 557-58 (1983) (same).

155. See Ernest Paper Prod., Inc. v. Mobil Chem. Co., Inc., No. CV95-7918 LGB(AJWX), 1997 WL 33483520, at *8-9 (C.D. Cal. 1997) (preempting Business and Professions Code section 17200 and tortious interference with economic relationships claims). Although it did not squarely address UTSA preemption, a 1999 Ninth Circuit ruling barred a common law tort claim because its remedial scheme was inconsistent with the CUTSA. See Cacique, Inc. v. Robert Reiser \& Co., 169 F.3d 619, 624 (9th Cir. 1999) (affirming ruling that party could not allege common law unfair competition to avoid California UTSA remedies).

156. See Accuimage Diagnostics Corp. v. Terarecon, Inc., 260 F. Supp. 2d 941, 953 (N.D. Cal. 2003) (comprehensive CUTSA preemption ruling on a common law misappropriation claim).

157. E.g., AirDefense, Inc. v. AirTight Networks, Inc., No. C 05-04615JF, 2006 WL 2092053, at*5 (N.D. Cal. July 26, 2006) (finding several tort claims UTSA-preempted on a motion to dismiss); Convolve, Inc. v. Compaq Comput. Corp., No. 00 CV 5141(GBD), 2006 WL 839022, at *5-6 (S.D.N.Y. Mar. 31, 2006) (applying CUTSA to broadly preempt several tort claims); Callaway Golf Co. v. Dunlop Slazenger Grp. Ams., Inc., 318 F. Supp. 2d 216, 220 (D. Del. 2004) (CUTSA; preempting negligence claim based on trade secret accusation). Although California Superior Court rulings are not generally available in online databases, many trial courts also ruled in favor of CUTSA preemption and thus sustained demurrers to various tort claims during these years. The author collected such rulings in conversation with practitioners around the state and also was involved in several such early rulings.

158. See Dig. Envoy, Inc. v. Google, Inc., 370 F. Supp. 2d 1025, 1034-35 (N.D. Cal. 2005) (CUTSA preemption of several alternative claims as a matter of law).

159. E.g., PostX Corp. v. Secure Data in Motion, No. C 02-04483 SI, 2004 WL 2663518 (N.D. Cal. 2004) (where court had already granted summary judgment on plaintiff's trade secret claim and plaintiff claimed to have uncovered new evidence of wrongdoing, court allowed plaintiff to proceed with an "unfair competition" claim, rejecting defendant's CUTSA preemption argument without analysis); Ali v. Fasteners for Retail, Inc., 544 F. Supp. 2d 1064 (E.D. Cal. 2008) (ruling, without significant analysis, that a conversion claim was not preempted by the CUTSA even though it mimicked a trade secret allegation).

160. K.C. Multimedia, Inc. v. Bank of Am. Tech. \& Operations, Inc., 171 Cal. App. 4th 939 (2009).

161. Id. at 957-60 (2009) (affirming "broad" preemption of claims including section 17200 unfair competition in pretrial trial court ruling based on the pleadings). 
Another court of appeal ruling a year later, Silvaco Data Systems v. Intel Corp., applied the same broad preemptive sweep and rejected a narrower interpretation of the CUTSA that would permit alternative pleading of tort claims to protect some undefined, non-secret category of information. ${ }^{162}$ These twin rulings make clear that CUTSA preemption is applied at the pleading stage, and applies whether or not the plaintiff's trade secret claim will ultimately succeed or fail. ${ }^{163}$ To ensure practical enforceability in the courts, the rulings make clear that a plaintiff cannot engage in artful wordplay and assert that the information at issue is, by way of example, "confidential but not secret" or "not secret but otherwise protectable" in order to avoid CUTSA preemption. ${ }^{164}$

Then, in a significant 2012 decision, a federal court ruled that litigants cannot use wordplay — for example, alleging tort claims and claiming that they protect "not trade secret" but still "confidential" information - to escape the preemptive scope of the statute, as interpreted by K.C. Multimedia and Silvaco. ${ }^{165}$ Similarly, in 2014, the same judge held that a party could not escape CUTSA preemption by choosing not to plead a trade secret cause of action, asserting instead soundalike tort claims. ${ }^{166}$

In the years since, state and federal courts applying California law have found tort claims preempted by the CUTSA in a vast number of decisions, over a wide variety

162. Silvaco Data Sys. v. Intel Corp., 184 Cal. App. 4th 210, 232-40, 239 n.22 (2010) overruled in part on unrelated ground by Kwikset v. Superior Court, 51 Cal. 4th 310, (2011) (affirming CUTSA preemption-based demurrer of claims including conversion and section 17200 unfair competition; footnote 22 explicitly rejects the lax construction of the CUTSA's preemption clause seen in some other jurisdictions). Although Silvaco expressed a preference for the word "supersession" rather than "preemption," there are good reasons to disagree. First, using "preemption" helps remind courts that CUTSA preemption is, along with patent preemption and copyright preemption, one of three related doctrines. Second, "supersession" implies that a tort claim was valid in California before the CUTSA's enactment date in 1985. But that is not always the case. Conversion claims, by way of example, were historically not recognized in California as vehicles for trade secret-type allegations. See Olshewski v. Hudson, 87 Cal. App. 282, 286 (1927) (rejecting conversion claim for trade secret-type customer list fact pattern); Adkins v. Model Laundry Co., 92 Cal. App. 575, 583 (1928) (same). Thus, "preemption" is the better word choice to suggest that efforts to circumvent the statute after 1985 are not permitted.

163. See Silvaco, 184 Cal. App. 4th at 232, 236; KC Multimedia, 171 Cal. App. 4th at 945-46, 95253 (plaintiff lost on summary judgment on trade secret claim).

164. See Silvaco, 184 Cal. App. 4th at 236, 238-39, 239 n.22. Silvaco's important footnote 22 rejected the plaintiff's urging to adopt the minority position on UTSA preemption-seen in a 2008 federal court ruling in Pennsylvania, cited in the footnote-which would allow a plaintiff to simply use different word choices or labels instead of "trade secret" to avoid UTSA preemption.

165. See SunPower Corp. v. SolarCity Corp., No. 12-CV-00694-LHK, 2012 WL 6160472, at*1 (N.D. Cal. Dec. 11, 2012) (widely-cited CUTSA preemption ruling following KC Multimedia and Silvaco and rejecting an argument that would have allowed pleading of alternative, overlapping tort claims based on business information said to be "confidential" but not a trade secret); see also Mattel, Inc. v. MGA Ent., Inc., 782 F. Supp. 2d 911, 986-87 (C.D. Cal. 2011) (same; "In an effort to align with the California courts that have addressed this issue, the Court concludes that CUTSA supersedes claims based on the misappropriation of confidential information, whether or not that information meets the statutory definition of a trade secret.").

166. See NetApp, Inc. v. Nimble Storage, Inc., 41 F. Supp. 3d 816, $839-40$ (N.D. Cal. 2014) (rejecting plaintiff's argument on motion to dismiss that tort claims could not be preempted because it did not allege a CUTSA cause of action; "such a rule would defeat preemption by allowing plaintiffs to intentionally omit CUTSA claims in favor of other claims"). 
of tort claims. These rulings cover such claims as conversion, ${ }^{167}$ unfair competition under Business and Professions Code section 17200, ${ }^{168}$ common law fraud, ${ }^{169}$ and unjust enrichment. ${ }^{170}$

The CUTSA also preempts discrete elements contained within certain tort claims, to the extent they seek to litigate an alleged misuse of confidential business information. For example, breach of fiduciary duty, which sometimes can overlap

167. See Silvaco, $184 \mathrm{Cal}$. App. 4th at 232-40 (conversion claim preempted); SunPower Corp., No. 12-CV-00694-LHK, 2012 U.S. Dist. LEXIS 176284, at $* 51$ (same on motion to dismiss). Notably, it makes no difference to the outcome if a plaintiff contends that the allegedly confidential information was embedded in tangible property, where the nexus of the claim centers on that allegedly confidential information and the tangible property is de minimis. See, e.g., Calendar Rsch. LLC v. StubHub, Inc., No. 2:17-cv-04062-SVW-SS, 2017 U.S. Dist. LEXIS 222745, at *15-16 (C.D. Cal. Aug. 16, 2017) (dismissing conversion claim as preempted: "[A]lleging that the same conduct amounted to both trade secret misappropriation and conversion simply because the trade secrets were contained in physical property is precisely what CUTSA preemption precludes."); Henry Schein, Inc. v. Cook, No. 16-cv-03166-JST, 2017 U.S. Dist. LEXIS 29183, at *14 (N.D. Cal. Mar. 1, 2017) (same as to claimed secrets embedded in "reports, inventory lists, customer account lists," and the like); $c f$. Snapkeys, Ltd. v. Google LLC, 442 F. Supp. 3d 1196, 1206-08 (N.D. Cal. 2020) (where plaintiff alleged that defendant did not return physical smartwatches onto which the plaintiff's software app had been loaded, finding that conversion claim was not UTSA-preempted, but that plaintiff could not claim any value of the software app as part of the alleged value of the tangible watches: "As discussed above, Snapkeys' conversion claim survives only insofar as Snapkeys seeks recovery for the value of its tangible physical property, rather than the value of the trade secrets or any other confidential information embedded in those prototypes.").

168. See Alta Devices, Inc. v. LG Elecs., Inc., No. 18-CV-00404-LHK, 2019 U.S. Dist. LEXIS 72952, at *22-31 (N.D. Cal. Apr. 30, 2019) (dismissing section 17200 claim as preempted); Swarmify, Inc. v. Cloudflare, Inc., No. C 17-06957 WHA, 2018 U.S. Dist. LEXIS 57035, at*15 (N.D. Cal. Apr. 3, 2018) (dismissing section 17200 claim as preempted, in part, to the extent it relied on allegations of misuse of nonpublic business information); GSI Tech., Inc. v. United Memories, Inc., No. 1:14-cv-01910 SKO, 2016 U.S. Dist. LEXIS 129568, at*25-27 (N.D. Cal. Sept. 25, 2015) (preempting section 17200 claim); Lifeline Food Co. v. Gilman Cheese Corp., No. 5:15-cv-00034-PSG, 2015 WL 2357246, at *10-13 (N.D. Cal. May 15, 2015) (preempting section 17200 claim on motion to dismiss); NetApp, Inc. v. Nimble Storage, Inc., 41 F. Supp. 3d 816, 840 (N.D. Cal. 2014) (same); SunPower, 2012 WL 6160472, at *1 (preempting section 17200 and other claims on motion to dismiss); Silvaco, $184 \mathrm{Cal}$. App. 4th at 232-40 (affirming CUTSA preemption of claims including section 17200); K.C. Multimedia, 171 Cal. App. 4th at $957-60$ (same).

169. See Snapkeys, Ltd., 442 F. Supp. 3d at 1204-07 (dismissing fraud cause of action with prejudice where plaintiff alleged that defendant made false promises in order to obtain and misuse confidential product information); Prostar Wireless Grp, LLC v. Domino's Pizza, Inc., 360 F. Supp. 3d 994, 1007 (N.D. Cal. 2018) (claims for deceit and negligent misappropriation CUTSA-preempted where plaintiff alleged that defendant engaged in fraud to obtain plaintiff's intellectual property); Peralta v. Cal. Franchise Tax Bd., 124 F. Supp. 3d 993, 1002 (N.D. Cal. 2015) (dismissing claims for constructive fraud and fraudulent concealment as UTSA-preempted where plaintiff who attempted to market an "invention" to the FTB claimed that it lied and misappropriated the information); Top Agent Network, Inc. v. Zillow, Inc. (Zillow I), No. 14-cv-04769-RS, 2015 U.S. Dist. LEXIS 176837, at*13 (N.D. Cal. Aug. 6, 2015); Top Agent Network, Inc. v. Zillow, Inc. (Zillow II) No. 14-cv-04769-RS, 2015 U.S. Dist. LEXIS 161556, at *23 (N.D. Cal. Apr. 13, 2015) (twice dismissing fraud and negligent misappropriation claims premised on allegation that defendant "purposefully misrepresented its intentions and omitted material information as part of a campaign to obtain confidential information").

170. See SOAProjects, Inc. v. SCM Microsys., Inc., No. 10-CV-01773-LHK, 2010 WL 5069832, at *10 (N.D. Cal. Dec. 7, 2010) (dismissing unjust enrichment claim, citing Silvaco). Notably, unjust enrichment is not a valid stand-alone cause of action under California law. See Melchior v. New Line Prod., Inc., 106 Cal. App. 4th 779, 793 (2003) (finding plaintiff's unjust enrichment claim copyrightpreempted, but also finding that "there is no cause of action in California for unjust enrichment"). 
with a trade secret allegation, but also can cover claims unrelated to misuse of allegedly nonpublic business information, has a checkered history in recent preemption rulings. ${ }^{171}$ The same is true of claims for breach of the employee duty of loyalty. ${ }^{172}$

\section{b. The California Uniform Trade Secrets Act Preempts Idea Submission Torts Premised on Confidential Information}

With this recent set of rules now firmly in place in California courts, the question is whether CUTSA trade secret preemption of tort causes of action also applies in the idea submission context, and not merely in traditional trade secret contexts such as employee departures.

As noted above, the distinction between trade secret and idea submission cases was always blurry, especially outside the confines of pitches to film and television studios. Throughout its history, plenty of California's trade secret cases have resembled idea submission cases, and vice versa.

In addition, the California courts have made clear that trade secret law applies to ideas - not just to fully-fleshed out developments and designs. In the 2014 case Altavion, Inc. v. Konica Minolta Systems Laboratory Inc., the trial court ruled against the defendant in a case where the plaintiff, a smaller business, had presented its ideas

171. See Genentech, Inc. v. JHL Biotech Inc., No. C 18-06582 WHA, 2019 U.S. Dist. LEXIS 99545, at *20-21 (N.D. Cal. June 13, 2019) (plaintiff given leave to amend its breach of duty claim to allege the portions that were not CUTSA-preempted, asserting that defendant covertly worked for an active competitor); Citcon USA, LLC v. Riverpay, Inc., No. 18-cv-02585-NC, 2018 U.S. Dist. LEXIS 216961, at *32-33 (N.D. Cal. Dec. 27, 2018) (breach of duty claim premised on transferring and downloading company filed dismissed as CUTSA-preempted); Anokiwave, Inc. v. Rebeiz, No. 18-CV-629 JLS (MDD), 2018 U.S. Dist. LEXIS 158346, at*9-12 (S.D. Cal. Sept. 17, 2018) (dismissing fiduciary duty claim as UTSA-preempted where it was premised on misuse of "Proprietary Information"); Johnson Controls, Inc. v. Therma, LLC, No. SACV 18-00636 AG (KESx), 2018 U.S. Dist. LEXIS 226239, at *9 (C.D. Cal. Aug. 17,2018 ) (where "all" of plaintiff's allegations as to breach of duty and other torts claims were premised upon "access and use" of the plaintiff's "confidential information," claims were dismissed as CUTSApreempted); Angelica Textile Serv., Inc. v. Park, 220 Cal. App. 4th 495, 499 (2013) (breach of fiduciary duty was not CUTSA-preempted because it alleged employee's effort to undermine the employer's ongoing business and to divert customers while still employed).

172. See Genentech, Inc., 2019 U.S. Dist. LEXIS 99545, at*20-21 (plaintiff given to amend its duty of loyalty claim to allege portions that were not CUTSA-preempted, asserting that defendant covertly worked for an active competitor); Citcon USA, LLC, 2018 U.S. Dist. LEXIS 216961, at*32-33 (duty of loyalty claim premised on transferring and downloading company file dismissed as CUTSA-preempted); Eurolog Packing Grp. North Am., LLC v. EPG Indus., LLC, No. LACV 18-02982-VAP (JEMx), 2018 U.S. Dist. LEXIS 22401, at *9 (C.D. Cal. Oct. 17, 2018) (denying motion to dismiss as to duty of loyalty claim where, in addition to allegations that would be CUTSA-preempted, plaintiff alleged that employee "deleted, altered, or blocked Plaintiff's business records, and ensured that other customer and sales data were not updated"); Anokiwave, Inc., 2018 U.S. Dist. LEXIS 158346, at *9-12 (S.D. Cal. Sept. 17, 2018) (dismissing fiduciary duty claim as CUTSA-preempted where it was premised on misuse of "Proprietary Information," noting that "[t]here would be no alleged breach if [defendant] had disclosed nonconfidential information. Thus, the claim does depend on the existence and disclosure of proprietary information."); Johnson Controls, Inc. v. Therma, LLC, No. SACV 18-00636 AG (KESx), 2018 U.S. Dist. LEXIS 226239, at *9 (C.D. Cal. Aug. 17, 2018) (where "all" of plaintiff"s allegations as to breach of the duty and other torts claims were premised upon "access and use" of the plaintiff"s "confidential information," claims were dismissed as CUTSA-preempted). 
for barcode-based document authentication under a nondisclosure agreement. ${ }^{173}$ The defendant was accused of using those ideas, which the court described as a "combination of design concepts," in unauthorized patent filings. ${ }^{174}$ The defendant argued on appeal that trade secret law does not reach ideas: "Generalized ideas and inventions are protectable by patents and thus cannot be trade secrets." 175 The appellate court rejected this notion, holding that "trade secret law may be used to sanction the misappropriation of an idea the plaintiff kept secret," and citing other cases where business concepts were protected by trade secret law. ${ }^{176}$

So, there is no doubt that inchoate business ideas are encompassed by California trade secret law. And there seems little reason to believe that the business ideas most commonly exploited in the entertainment industry - scripts, plots, and formatsshould be classified differently. Nothing in the text of the CUTSA suggests that it is limited to particular industries or fields of business endeavor. Put simply, if an entertainment idea meets the tests for trade secrecy, and if it was misappropriated, there is no reason a plaintiff could not bring a CUTSA claim to seek redress.

There also is little reason to believe that CUTSA trade secret preemption does not eliminate California tort claims that are premised upon the confidentiality of the ideas, such as breach of confidence, when those claims arise in the idea submission context. A breach of confidence claim requires, as the label suggests, that the information in dispute actually be confidential. As one court put it, "an idea must be confidential and novel to warrant protection" and allow such a claim to succeed. ${ }^{177}$ Thus, a breach of confidence claim should fail where the information is available from other sources. ${ }^{178}$

However, breach of confidence cases might be read as though the question is a subjective one-“Did the plaintiff keep it confidential?"-rather than an objective question, as the CUTSA would ask it- "Is the information confidential, or can it instead be found in the public domain?" That ambiguity is what makes it tempting for litigants, as it may offer standards below those that would be imposed by the statutory trade secret regime.

California courts have often found breach of confidence claims CUTSApreempted in trade secret cases, including in the leading appellate case K.C. Multimedia. ${ }^{179}$ And there seems little doubt that historical breach of confidence

173. See Altavion, Inc. v. Konica Minolta Sys. Lab’y Inc., 226 Cal. App. 4th 26, 34 (2014).

174. Id. at 47.

175. Id. at 53

176. Id. at 56 .

177. Tele-Count Eng'rs, Inc. v. Pac. Tel. \& Tel. Co., 168 Cal. App. 3d 455, 462-65 (1985) (describing elements of cause of action).

178. See Heckenkamp v. Ziv Television Programs, Inc., 157 Cal. App. 2d 293, 300-01 (1958) (rejecting plaintiffs' claims for breach of confidence and unfair competition because 1947 amendments to Civil Code section 980 had "abrogated the rule of protectibility [sic] of an idea," and plaintiff claimed only the copying of a mere idea for a show involving the Highway Patrol, and also because the "files which were the basis for plaintiff's program idea were files of a department of state government," in which plaintiff had no property interest).

179. K.C. Multimedia, Inc. v. Bank of Am. Tech. \& Operations, Inc., 171 Cal. App. 4th 939, 95760 (2009) (CUTSA preemption of unfair competition, breach of confidence, and tortious interference with 
cases, many of which read just like trade secret cases, would be CUTSA-preempted today. ${ }^{180}$ To be sure, some CUTSA preemption cases decided before, or just after, the 2009-2010 court of appeal rulings that solidified California's position, got things wrong; but such decisions have been criticized for failing to follow precedent and they carry no weight today. ${ }^{181}$

There is no reason, then, that the CUTSA does not also preempt breach of confidence claims in the idea submission context. The same is true for other, similar tort claims - which, like breach of confidence, are frequently found CUTSApreempted in trade secret cases - such as unfair competition, common law misappropriation, and the like. When used in the idea submission context, these torts merely advance the same theory of wrongdoing under different labels.

Given these overlaps, it is perhaps surprising that CUTSA preemption of tort claims has not come up more frequently in idea submission cases. Indeed, it appears that California litigants have raised the issue only twice in reported rulings - though one court did not reach the question, ${ }^{182}$ and the other dodged the question in a

contract claims); see also Wang v. Palo Alto Networks, No. C 12-05579 WHA, 2013 WL 415615, at*4 (N.D. Cal. Jan. 31, 2013) (applying K.C. Multimedia to dismiss breach of confidence claim as CUTSApreempted); SunPower Corp. v. SolarCity Corp., No. 12-CV-00694-LHK, 2012 WL 6160472, at *3-9 (N.D. Cal. Dec. 11, 2012) (preempting several claims including breach of confidence on motion to dismiss); Convolve, Inc. v. Compaq Comput. Corp., No. 00 CV 5141 (GBD), 2006 U.S. Dist. LEXIS 13848, at *27 (S.D.N.Y. Mar. 28, 2006) (applying California law, preempting several tort claims including breach of confidence).

180. See, e.g., Ralph Andrews Prod., Inc. v. Paramount Pictures Corp., 222 Cal. App. 3d 676, 679 (1990) (case arose on pre-1985 facts, centering on a claim for "unfair competition" where company alleged that its former employee "stole an idea for a television game show" and offered it to defendant studio under conditions where defendant should have been on constructive notice that idea did not belong to former employee; court reversed finding for defendant for further findings on notice issue); see also TeleCount Eng'rs, 168 Cal. App. 3d at 462-65 (affirming judgment for defendants on breach of confidence claim where plaintiff, a contractor for a telephone company, alleged that the telephone company had shared plaintiff's confidential forms with a rival contractor; court upheld jury verdict that forms were not protectable despite minor errors in jury instructions informing jury that the information at issue had to be "substantially secret").

181. See SocialApps, LLC v. Zynga, Inc., No. 4:11-CV-04910 YGR, 2012 WL 381216, at *3-4 (N.D. Cal. Feb. 6, 2012) (asserting, without following K.C. Multimedia and Silvaco, that "[w]hile CUTSA might preempt any relief with respect to information that is a protectable trade secret, SA may still be entitled to recover on a breach of confidence theory for any non-trade secret information."); see also Think Village-Kiwi LLC v. Adobe Sys., Inc., No. C 08-04166 SI, 2009 WL 902337, at *2 (N.D. Cal. Apr. 1, 2009) (same and denying UTSA preemption as to breach of confidence and common law misappropriation claims); cf. Wang v. Palo Alto Networks, No. C 12-05579 WHA, 2013 WL 415615, at*4 (N.D. Cal. Jan. 31,2013 ) ("To the extent that SocialApps can be interpreted as holding that the same nucleus of fact can support both a trade-secret and a breach-of-confidence claim, that interpretation is not persuasive because it conflicts with K.C. Multimedia.").

182. See Carr v. AutoNation, Inc., No. 2:17-cv-01539-JAM-AC, 2018 U.S. Dist. LEXIS 137566, at *7-8 (E.D. Cal. Aug. 14, 2018) (where the plaintiff submitted ideas related to the automobile wrecking industry and alleged that the defendant later used them, the defendant moved to dismiss the plaintiff's "breach of contract implied in fact claim" as CUTSA-preempted, court instead dismissed that claim on an unrelated ground). As discussed below, I do not believe that the CUTSA preempts a Desny cause of action. 
footnote. ${ }^{183}$ The answer may simply be, again, that trade secret cases and idea submission cases arise in different cultural contexts, and courts and practitioners do not think to connect one to the other. In addition, those invested in idea submission cases spent many years battling over copyright preemption, and by the time the Ninth Circuit had resolved those questions, California's rules for CUTSA preemption were only just being set in stone. The difference of just ten years may go far in explaining why this other form of IP preemption did not receive the treatment copyright preemption received in the idea submission cases.

\section{c. California's Uniform Trade Secrets Act Preemption Does Not Apply To Desny Claims.}

If California's Uniform Trade Secrets Act is found to preempt tort claims often seen in idea submission cases, must the same hold true for Desny claims, where the plaintiff alleges breach of an implied-in-fact contract?

The simple answer is: No, the CUTSA should not preempt a contract-based Desny claim. The CUTSA's preemption clause expressly does not apply to contract claims. ${ }^{184}$ The statute's legislative history is also clear. It states: "This Act ... applies to duties imposed by law in order to protect competitively sensitive information. It does not apply to duties voluntarily assumed through an express or an implied-in-fact contract." 185 More generally, outside the employment context, where special rules apply for public policy reasons under Business and Professions Code section 16600, it is less clear whether California contract law would block two commercial parties from negotiating an agreement that would oblige one or both of them to protect information known to be publicly available. At least one historical case allowed a contract claim over non-secret information, analogous to a Desny claim over non-novel ideas. ${ }^{186}$

183. See Interserve, Inc. v. Fusion Garage PTE, Ltd., No. C 09-5812 RS (PVT), 2010 U.S. Dist. LEXIS 87145 , at *1-2, *28 n.9 (N.D. Cal. Aug. 24, 2010) (plaintiff alleged that defendant misused ideas stemming from a business collaboration "in an attempt to bring to market a tablet computer" and brought a self-styled cause of action called "misappropriation of business ideas"; the court dismissed with leave for the plaintiff to allege a Desny claim if it could, and noted that the defendant had also asserted that the tort claim should be CUTSA preempted, explaining that "[s]uch preemption would arise to the extent [plaintiff] is attempting to recover for misappropriation of trade secrets in the guise of a different claim for relief. [Plaintiff] insists, however, that it has not pleaded, and does not intend to ever argue, that any of the 'business ideas' it contends were misappropriated were trade secrets."). To the extent the court was agreeing with, rather than merely reporting, the plaintiff's argument, this would clearly be an invalid position in light of Silvaco, which it did not mention (although Silvaco was issued some four months earlier).

184. See CAL. Civ. CODE $§ 3426.7$ (b)(1) (West 2020) ("This title does not affect ... contractual remedies, whether or not based upon misappropriation of a trade secret.").

185. Assembly Committee Digest for AB 501 (April 25, 1983) (quoting UTSA Commissioners' Comment to model § 7) (on file with author).

186. For example, in 1940 the California Supreme Court affirmed a judgment against a defendant which had accepted wooden patterns for a microphone product under a verbal agreement in order to manufacture parts for the plaintiff, but which had made additional parts and sold them on the side. Hollywood Motion Picture Equip. Co. v. Furer, 16 Cal.2d 184, 185 (1940). Although the defendant 
It does not appear that any court has squarely addressed whether the CUTSA preempts or does not preempt a claim for breach of an implied-in-fact contract. That may be because the answer is already clear from existing sources. ${ }^{187}$

This answer also corresponds to the different public policies pursued in each of the separate IP regimes. There is a critical difference between Desny cases and California trade secret law, and this difference precludes a complete merger between the two. Both offer protection for weaker parties against more powerful parties, but they do so in different ways. First, California trade secret and employee mobility laws protect the rights of employees changing jobs by, among other things, voiding contracts and precluding tort actions that seek to impose restrictions on the postemployment use of non-secret information. As discussed above, these protections have been advanced further through recent judicial bans on non-solicitation covenants, and as a result of California's thorough rejection of the so-called "inevitable disclosure" theory. ${ }^{188}$

By contrast, the Desny doctrine uses an implied contract theory to protect idea submissions offered to studios even if the plaintiff's idea is not entirely novel, albeit in a narrowly defined context of offer and acceptance. As a result, the former approach promotes a robust public domain free of impediments for departing employees, while the latter can protect ideas even if they are to some degree available elsewhere.

In light of this crucial difference, a complete merger of these two areas of state intellectual property law is neither achievable nor desirable. Nonetheless, merging these two legal regimes to some degree, through CUTSA trade secret preemption of tort claims, seems mandated by case law. To be sure, the trade secret laws do not preempt contract claims, which are the heart of the Desny doctrine. Although a Desny claim is narrower than a trade secret claim or a claim for breach of a written nondisclosure contract — not only because its elements are difficult to satisfy, but also because it has a shorter statute of limitations and more limited damages - it will

protested that the information was not "secret," the court held that a bailment had been established and that " $[t]$ he mere fact that the ingenious principle materialized in the thing bailed may be known to all the world would not deprecate the sanctity of the contract between the bailor and the bailee." Id. at 188. In modern parlance, the court implied a non-use license term into the oral contract, notwithstanding that the concepts embedded in the wooden items were not trade secrets.

187. At least two courts have ruled on whether the CUTSA preempts a California cause of action for breach of the implied covenant of good faith and fair dealing. This question is tangled because this hybrid claim has both contract and tort attributes. One, Convolve, Inc. v. Compaq Comput. Corp., No. 00 CV 5141(GBD), 2006 WL 839022, at *9 (S.D.N.Y. Mar. 31, 2006), found that the claim was not preempted because it "is a contractual claim which the California UTSA expressly allows." Another found the claim preempted if it sought tort recovery. See Swarmify, Inc. v. Cloudflare, Inc., No. C 1706957 WHA, 2018 U.S. Dist. LEXIS 57035, at *4-11 (N.D. Cal. Apr. 3, 2018) ("To the extent that [plaintiff's] claim for breach of the implied covenant seeks tort recovery separate and aside from its claim for breach of written contract, it runs headlong into CUTSA supersession by relying on the same nucleus of operative facts as [its] trade secret misappropriation claims.").

188. See FLIR Sys., Inc. v. Parrish, 174 Cal. App. 4th 1270, 1276 (reaffirming California's prohibition of "inevitable disclosure" injunctions and narrowly construing the phrase "threatened misappropriation" in the CUTSA to mean something beyond the former employer's fears and suspicions that a former employee will violate the law). 
continue to exist. ${ }^{189}$ Still, clearing away the underbrush of duplicative and vague tort claims in the Desny context would offer the same benefit seen in trade secret law, where forcing similar claims into a single channel has promoted predictability and fostered more uniform rulings.

\section{CONCLUSION}

California courts can and should bring the state's idea submission and trade secret regimes closer together, to better develop the defense of independent derivation in trade secret law, and to preempt nebulous tort claims in idea submission law that are premised on allegedly nonpublic information. At the same time, the core causes of action-Desny claims, trade secret misappropriation claims, and claims for breach of a written agreement — would remain the same.

189. For example, the baseline statute of limitations for breach of an implied contract is only two years, compared to three years for a trade secret claim and four years for breach of a written contract. See CAL. Civ. Proc. Code $\S 339$ (limitations period for contract not in writing); CaL. Civ. CodE $\S 3426.6$ (West 2020) (limitations period for trade secret claim); see also CAL. CIV. Proc. CODE $§ 337$ (West 2020) (limitations period for written contract). Also, a Desny claim does not lead to the panoply of remedies available under the CUTSA, and there is also no case suggesting that a Desny claim could lead to the unjust enrichment damages that California permits for breach of written confidentiality agreements. See generally Ajaxo, Inc. v. E*Trade Grp., Inc., 135 Cal. App. 4th 21 (2006) (case for breach of confidentiality contract relied on unjust enrichment remedy and CUTSA case law). 